I NTER NATIONAL MONETARY FUND

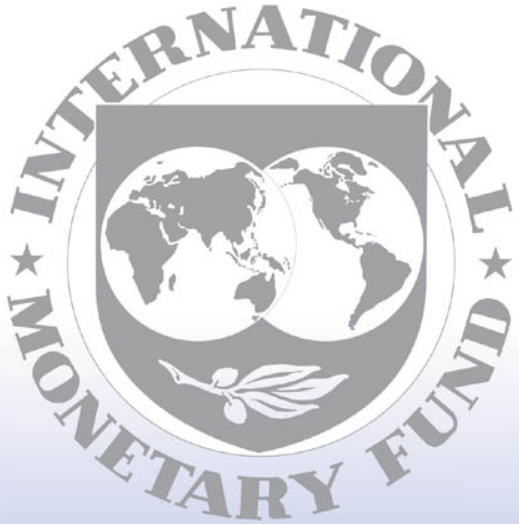

Staff

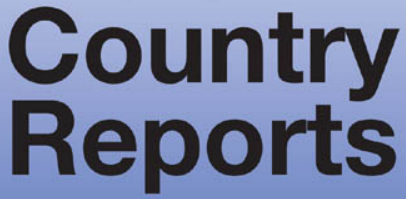




\section{Cape Verde: Fifth Review Under the Three-Year Arrangement Under the Poverty Reduction and Growth Facility-Staff Report; Press Release on the Executive Board Discussion; and Statement by the Executive Director for Cape Verde}

In the context of the fifth review under the three-year arrangement under the Poverty Reduction and Growth Facility with Cape Verde, the following documents have been released and are included in this package:

- $\quad$ the staff report for the fifth review under the three-year arrangement under the Poverty Reduction and Growth Facility, prepared by a staff team of the IMF, following discussions that ended on November 17, 2004, with the officials of Cape Verde on economic developments and policies. Based on information available at the time of these discussions, the staff report was completed on January 13, 2005. The views expressed in the staff report are those of the staff team and do not necessarily reflect the views of the Executive Board of the IMF.

- $\quad$ a Press Release summarizing the views of the Executive Board as expressed during its January 31, 2005 discussion of the staff report that completed the review.

- $\quad$ a statement by the Executive Director for Cape Verde.

The documents listed below have been or will be separately released.

Letter of Intent sent to the IMF by the authorities of Cape Verde*

Memorandum of Economic and Financial Policies by the authorities of Cape Verde*

Technical Memorandum of Understanding*

*May also be included in Staff Report

The policy of publication of staff reports and other documents allows for the deletion of market-sensitive information.

To assist the IMF in evaluating the publication policy, reader comments are invited and may be sent by e-mail to publicationpolicy@imf.org.

Copies of this report are available to the public from

International Monetary Fund • Publication Services

$70019^{\text {th }}$ Street, N.W. • Washington, D.C. 20431

Telephone: (202) 623-7430 • Telefax: (202) 623-7201

E-mail: publications@imf.org • Internet: http://www.imf.org

Price: $\$ 15.00$ a copy

International Monetary Fund

Washington, D.C. 
INTERNATIONAL MONETARY FUND

\author{
CAPE VERDE \\ Fifth Review Under the Three-Year Arrangement Under \\ the Poverty Reduction and Growth Facility \\ Prepared by the African Department \\ (In consultation with other departments) \\ Approved by Thomas Krueger and Mark Plant
}

January 13, 2005

\begin{abstract}
- $\quad$ PRGF arrangement. A three-year PRGF arrangement for SDR 8.64 million (90 percent of quota) was approved by the Executive Board on April 10, 2002. Five loans totaling SDR 6.15 million have been disbursed, and another SDR 1.23 million becomes available at the completion of this review.

- $\quad$ Program performance. The program is largely on track. All quantitative and structural performance criteria for end-June 2004 and all indicative targets for end-September 2004 were observed, as were all but three structural benchmarks. Of these three, one has now been met and the authorities are making progress toward complying with the other two.

- $\quad$ Letter of Intent and Memorandum of Economic and Financial Policies. The authorities reaffirm their commitment to the fiscal and monetary restraint needed to sustain the exchange rate peg to the euro, as well as to measures to support poverty reduction and enhance international competitiveness.
\end{abstract}

- $\quad$ Successor program. The authorities expressed strong interest in a successor arrangement with the Fund. Discussions are under way with the Fund staff on what form of arrangement would be the most appropriate.

- Discussions during the mission. From November 3 to 17, 2004, the staff team met with Prime Minister José Maria Neves, Finance Minister João Serra, Governor Carlos Augusto de Burgo of the Central Bank of Cape Verde, and other officials and private sector representatives. The team comprised Mr. MacFarlan (Head), Ms. Loukoianova, Mr. Melhado (all AFR), and Mr. Mooney (SEC). Mr. Ondo Mañe (Executive Director) visited Cape Verde for discussions with the authorities during the mission. Mr. Sidi Bouna (OED) accompanied the mission, as did Mr. Van Houtte from the World Bank. 


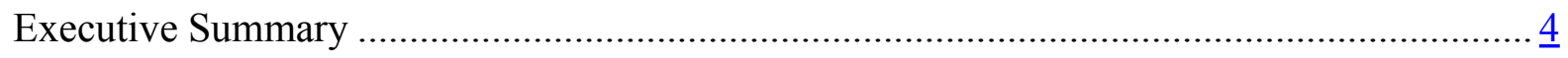

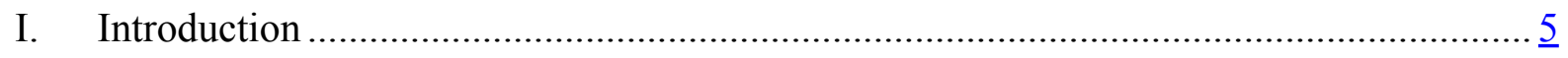

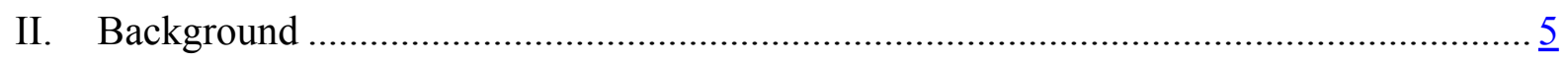

III. Program Implementation Through September 2004 ..................................................... $\underline{6}$

IV. Report on the Discussion......................................................................................

A. Macroeconomic Framework for the Remainder of 2004 and for $2005 \ldots \ldots \ldots \ldots \ldots \ldots . .10$

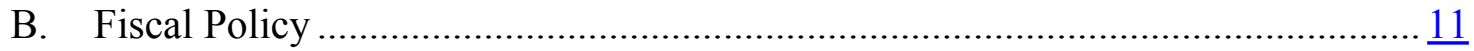

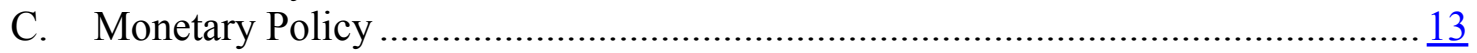

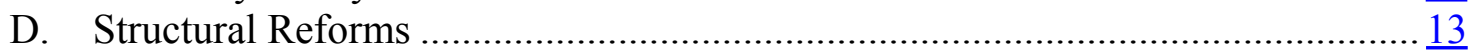

E. The Poverty Reduction Strategy Paper …………………………………….....

V. Discussion of a Successor Program ………………….............................................

VI. Statistical Issues .................................................................................................

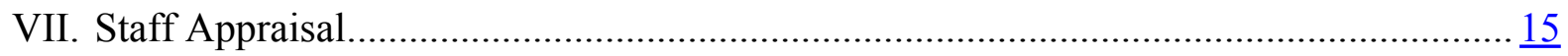

Figures

1. Selected Economic Indicators, 1995-2004 …….................................................. $\frac{17}{18}$

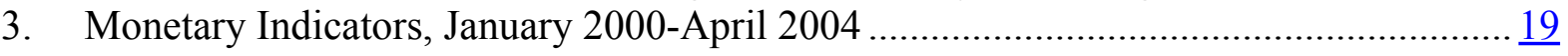

Tables

1. Selected Economic and Financial Indicators, 2001-05 …………………………....... 20

2. Annual Fiscal Operations of the Central Government, 2001-05 ................................... 21

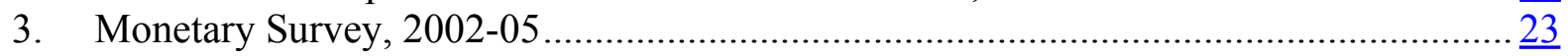

4. Balance of Payments, 2001-05 ............................................................................

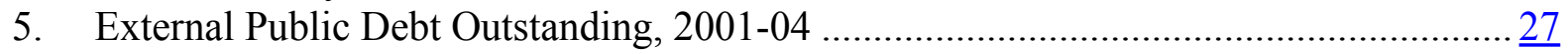

6. Vulnerability Indicators, 1998-2004 ………………............................................. $\frac{28}{29}$

7. Proposed Schedule of Disbursement Under the PRGF Arrangement, 2002-05 .............. $\frac{29}{29}$

8. Millennium Development Goals ……………………............................................... $\frac{30}{30}$

Boxes

1. Government's Financial Relations with Electra...........................................................

2. Structural Conditionality .................................................................................. 
Appendices

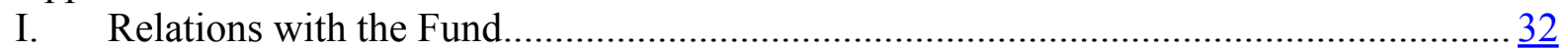

II. Relations with the World Bank ………………................................................

III. Letter of Intent................................................................................................

Attachment I: Supplementary Memorandum of Economic and Financial Policies for November 2004-April 2005 ……………………….... 40

Attachment II: Technical Memorandum of Understanding ...................................... $\underline{50}$ 


\section{EXECUTIVE SUMMARY}

- $\quad$ Cape Verde's economic and policy performance is largely on track vis-à-vis the PRGF objectives. All quantitative and structural performance criteria for end-June 2004 and all indicative targets for end-September 2004 were observed, as were all but three structural benchmarks. Of these three, one has now been met and the authorities are making progress toward complying with the other two.

- GDP growth of 4 percent is now expected in 2004 , lower than the 5.5 percent originally projected as a result of short-term difficulties in the agricultural sector and in the public investment program. Growth is projected to pick up to about 6 percent in 2005, supported by strong private and public investment. Inflation is expected to remain low.

- $\quad$ Fiscal performance has been sound. With revenues under the new VAT exceeding expectations and expenditures growing in line with the program, the fiscal deficit in 2004 is likely to be substantially smaller than the program target. For 2005, further improvements in tax administration and revenues, together with firm restraint on recurrent expenditures, are expected to lead to a higher primary surplus and an overall deficit of 3.7 percent of GDP.

- $\quad$ Money and credit have been growing in line with the program in 2004, and the monetary framework for 2005 is designed to support ongoing price stability and the accumulation of international reserves. At end-September 2004, the net international reserves of the Bank of Cape Verde exceeded the program target by a comfortable margin. Reserve coverage is forecast to increase from 2.2 months of imports at end-2004 to 2.4 months at end-2005.

- The government is pushing ahead with its structural reform agenda. It is committed to completing most of its privatization program by the end of 2005, and is making progress in clearing its outstanding debts to Electra (the electricity and water supplier). These steps are being accompanied by the development of associated regulatory capacities and tariff adjustment mechanisms.

- $\quad$ The Poverty Reduction Strategy Paper has recently been completed. In the Joint Staff Advisory Note on the PRSP, the IMF and World Bank staffs urge the authorities to continue to seek external grants and concessional financing in support of the PRSP investment program. The staffs also emphasize the need to improve domestic resource mobilization and to strengthen prioritization within the PRSP.

- $\quad$ The government has reiterated its desire to maintain a strong working relationship with the Fund after the current PRGF arrangement comes to an end. In this regard, the staff will discuss with the authorities the possibility of moving to a low-access PRGF. This would give due recognition to the authorities' sound economic management over recent years and provide a solid framework for ongoing macroeconomic stability. 


\section{INTRODUCTION}

1. The government of Cape Verde requests the completion of the fifth review under the PRGF-supported program. In the Letter of Intent (Appendix III) and its attached Supplementary Memorandum of Economic and Financial Policies (MEFP), the authorities review economic and policy progress to September 2004, and set out policies to be implemented through the end of the program. The government also requests a short extension of the arrangement to end-July 2005 to provide sufficient time for completion of the final review and for the final disbursement. Progress will be monitored through quantitative performance criteria for end-December 2004, as well as structural performance criteria and benchmarks for the remainder of the arrangement.

\section{BACKGROUND}

\section{Cape Verde has achieved a level of economic and human development that, if backed by sound economic policies, appears to position the country well to attract further investment and maintain robust growth. Several characteristics stand out (see the table):}

- GDP per capita is about three to five times that of its closest neighbors in West Africa.

- Literacy rates, life expectancy, and gender equality are also relatively high, and child mortality rates are relatively low-implying that Cape Verde has either attained or is within reach of a number of Millennium Development Goals (Table 8).

- Indicators of institutional quality, such as political stability, rule of law, and control of corruption, are substantially above regional averages.

These attributes should provide a firm basis for implementation of the government's development strategy, which is focused on growth of the tourism sector, the promotion of Cape Verde as a shipping and airline hub, and private sector-led growth more generally.

Cape Verde: Selected Cross-country Indicators, 2002

\begin{tabular}{|c|c|c|c|c|c|}
\hline & Cape Verde & Ghana & Mali & Senegal & $\begin{array}{c}\text { Sub-Saharan } \\
\text { Africa (avg) }\end{array}$ \\
\hline \multicolumn{6}{|l|}{ Governance indicators $1 /$} \\
\hline Political stability & 0.81 & -0.11 & -0.10 & -0.36 & -0.53 \\
\hline Rule of law & 0.19 & -0.15 & -0.54 & -0.20 & -0.68 \\
\hline Control of corruption & 0.33 & -0.40 & -0.32 & -0.17 & -0.62 \\
\hline GDP per capita (current US\$) & 1405.1 & 309.4 & 293.9 & 503.3 & 908.6 \\
\hline GDP per capita, PPP (constant 1995 international \$) 2/ & 4710.7 & 1895.9 & 864.8 & 1411.9 & 2347.0 \\
\hline Life expectancy at birth, total (years) & 69.1 & 54.9 & 40.9 & 52.3 & 48.5 \\
\hline Literacy rate, adult total (\% of people ages 15 and above) & 75.7 & 73.8 & $\ldots$ & 39.3 & 63.5 \\
\hline Mortality rate, infant (per 1,000 live births) & 29.0 & 60.0 & 122.0 & 79.0 & 95.9 \\
\hline
\end{tabular}

Source: World Bank: World Development Indicators and Governance Indicators.

$1 /$ The method used to calculate each of the six governance indices gives it approximately a unit normal distribution, with an increase always meaning a better quality of institution

2/ An international dollar has the same purchasing power over GDP as a U.S. dollar in the United States. 
3. Nevertheless, the country faces a number of important challenges. In particular:

- Unemployment, poverty, and inequality remain high, as discussed in the recently released Poverty Reduction Strategy Paper (PRSP).

- Domestic agricultural and energy potential is low, leading to high import requirements and terms of trade vulnerabilities.

- Costs of energy distribution, shipping, and air links across the archipelago are high, reducing external competitiveness and leading to pressures for public subsidies for the companies concerned.

- $\quad$ Previous elections, including in 1996 and 2001, have been preceded by strong growth of public expenditures, resulting in serious macroeconomic imbalances and the depletion of foreign exchange reserves. The next elections are expected in early 2006.

4. Responding to these pressures and challenges, the government's economic strategy has emphasized both fiscal restraint and wide-ranging structural reforms. In particular, the authorities have maintained a prudent fiscal stance, providing scope for increases in priority spending - especially on health, education, and infrastructure - while also supporting growth in international reserves to back the exchange rate peg. Structural reforms have focused on restructuring and privatizing key public enterprises, together with clearing arrears and reducing pressures for subsidies. While some delays emerged in early 2004 in the lead-up to municipal elections, the authorities have recently signaled their determination to regain momentum in these reform efforts. This strategy has supported strong economic performance over recent years, including robust GDP growth and low inflation.

\section{Program Implementation Through SePtember 2004}

\section{Cape Verde's economic and policy performance through September 2004 remained}

sound. Growth was strong, inflation was very low, fiscal and monetary policies were on track, and the authorities moved ahead in their structural reform agenda. All performance criteria for end-June and indicative targets for end-September were observed. Most structural benchmarks were also met, although three were missed. The benchmark on concluding a report on the government's financial liabilities to Electra (the electricity and water company) was not observed, as negotiations are still proceeding on this issue (see below). An assessment of the cost of tax exemptions and incentives was delayed because of difficulties in securing a consultant, but has since been conducted with technical assistance from the Fund. ${ }^{1}$ As signaled in the fourth review, a benchmark on the adoption of regulations for the methodology to determine electricity and water tariffs by the independent Economic Regulatory Agency (ARE) has been delayed to end-2004, with the World Bank assisting the authorities in this project.

\footnotetext{
${ }^{1}$ An FAD technical assistance mission visited Praia in October in order to conduct this assessment. The report will be presented to the authorities in early 2005 .
} 
6. GDP growth remains robust and is expected to reach around 4 percent in 2004. This is lower than the 5.5 percent originally projected, however, as a result of short-term difficulties in the agricultural sector and in the public investment program. In particular, agricultural output has been hit by a recent locust infestation in one region as well as drought, and construction growth is lower than expected owing to administrative delays in implementing some public investment projects.

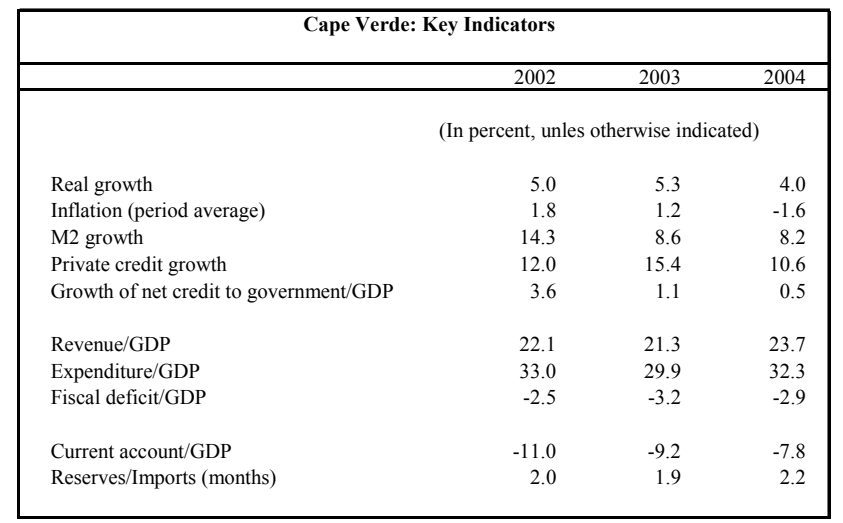

7. Inflation remained subdued through October 2004. Strong agricultural performance during the previous growing season helped to lower food prices, with further downward pressure on prices resulting from reductions in customs tariffs at the beginning of the year. While retail fuel tariffs were adjusted, albeit with some delay (see below), to reflect the higher price of oil imports, the full impact of higher energy prices has been partially dampened by constant electricity and water tariffs for domestic consumers and by a government subsidy on cooking gas used by rural families.

8. Fiscal policy remains on track. The overall fiscal deficit (including grants) in 2004 is now expected to be 2.9 percent of GDP, compared with the program projection of 5.6 percent of GDP. This improvement is fully attributable to the stronger-than-expected performance of revenues (as discussed in the next paragraph). As signaled in the previous review, recurrent expenditures have been revised up compared with the 2004 program to support increased hiring and training of teachers, doctors, and security personnel. Agreement was also reached on a small increase in extraordinary spending, intended to help address rural difficulties arising from the locust infestation, drought, and higher fuel prices. Offsetting these increases, however, is restraint in other recurrent spending components and a lower-than-planned level of public investment.

9. Considerable progress has been achieved in strengthening revenues. Of particular note is that revenues from the new VAT, introduced in January 2004, have exceeded expectations, supported by implementation of a number of structural fiscal reforms. This strong performance of the VAT, which now accounts for one third of total tax revenue, more than offset a significant (51 percent) fall in revenue from customs duties and excises owing to decreased tariff rates and the elimination of most excise taxes. ${ }^{2}$ As a result, overall tax revenues increased by 3 percent of GDP from January to September 2004 compared with the same period in the preceding year.

\footnotetext{
${ }^{2}$ Customs duties have been reduced for almost 80 percent of imports, and many specific consumption taxes have been eliminated in favor of one excise tax that covers a limited number of goods.
} 
10. Money and credit growth has been in line with the program (Table 3). Credit to the economy grew by an estimated 11.5 percent in the year to September 2004, substantially slower than in 2003 on account of less buoyant overall economic activity and an adjustment in the composition of foreign and domestic assets and liabilities in the commercial banking system.

11. The large external current account deficit is expected to narrow somewhat in 2004 compared with the program and the 2003 outturn and, at end-September 2004, the net international reserves of the Bank of Cape Verde exceeded the program target by a comfortable margin. The current account improvement is mainly due to lower imports, while revenues from tourism and remittances have remained relatively robust. The adverse impact of the increase in international oil prices (in dollar terms) was partly offset by the appreciation of the euro (and hence the Cape Verde escudo) against the dollar. Overall, the escudo's appreciation against the dollar does not appear to have harmed economic performance, in part owing to strong trade linkages with Europe, and the fact that most tourism and remittance flows also originate in the European Union (EU). Furthermore, Cape Verde's real effective exchange rate has depreciated, helped by low domestic inflation. Nevertheless, with Cape Verde's overall cost structure substantially above many of its competitors - particularly in the important tourism sector-appreciation of the currency could well become a source of concern.

12. In response to the oil price shock, pump prices for gasoline and diesel were recently adjusted after some delay. Applying the mechanism adopted in February 2004 to adjust retail fuel prices in response to changes in the import price of oil products, the regulatory agency ARE introduced a first round of price changes in June 2004. However, the subsequent adjustment did not occur until November. Representatives of ARE attributed this delay to some difficulties that it encountered in its negotiations with the two oil importing companies regarding their costs for importing and distributing oil products. ARE expects that more frequent and systematic price adjustments will occur from January 2005 onward, by which time such difficulties should be resolved.

13. The government is making progress in clearing its outstanding debts to Electra, the electricity and water supplier (see Box 1). After some difficulties and delays, negotiations are now under way with the majority shareholders of Electra to identify the government's outstanding liabilities. These liabilities arise, in part, from non-adjustment of electricity tariffs during 2000-02. When the arbitration process is completed, the government plans to agree on a payment plan to settle its liabilities. Furthermore, by end-2004 ARE intends to adopt regulations for a methodology to adjust electricity and water tariffs in response to changes in input costs (this step is a structural benchmark under the program). The government has cleared arrears to Cape Verde Telecom and Shell Oil, and is in the process of clearing arrears to other suppliers.

\section{In pushing ahead with its structural reform agenda, the government has recently} committed to completing most of its privatization program by the end of 2005 . The privatization process is under way for a maritime transport company (Arca Verde), a dockyard (CABNAVE), the pharmaceutical manufacturer and distributor (EMPROFAC), and a fish freezing and storage company (Interbase). The port operator (ENAPOR) will also privatize two major ports in 2005, and tender concession contracts for the remaining operations. 


\section{Box 1. Government's Financial Relations with Electra}

Electra is responsible for production and distribution of electricity and water (produced through desalination plants) in Cape Verde. Both services are produced island-by-island, as there are no interisland power or water connections, but a uniform tariff structure is applied throughout the archipelago. Oil and oil products, all of which are imported, are key inputs for both electricity and water production. Investment by Electra in further power generation and water desalination capacity, as well as improvements in transmission infrastructure, are vital to support development of tourism and industry.

In 1999, after an international bidding process, the government sold 51 percent of the shares of Electra to Electricidade de Portugal (EDP) and Agua de Portugal (ADP). Cape Verde municipalities were granted 15 percent of the shares and the government retained the remaining 34 percent. The contract entailed a license to produce electricity and water for 30 years. In addition, a concession agreement was signed granting Electra exclusive distribution rights for 36 years.

The financial liabilities that the government has incurred toward Electra over recent years stem from three main sources:

- The non-adjustment of energy tariffs to reflect prevailing input prices (mainly of oil). The failure to adjust tariffs during 2000-02 created sizable liabilities from the government to Electra, and hence from Electra toward domestic oil suppliers. The precise magnitude of the government's liabilities is currently the subject of negotiations between the government and the majority shareholders.

- $\quad$ Past subsidies provided on diesel used for generation of electricity in rural areas. To determine the extent of these liabilities, which are also under negotiation, the government has requested that Electra provide data to identify separately the diesel consumption of electricity generation plants in the main urban areas as opposed to rural areas. Looking ahead, the government intends that diesel subsidies for poorer rural households should be funded by urban consumers, so that there would continue to be no overall budgetary subsidy to Electra.

- Consumption of electricity and water by the government sector. The public sector has at times incurred payment arrears for its own energy and water consumption. In the first half of 2004, the government made a one-off payment to Electra to settle the outstanding amounts due, and claims to have remained current in its payments since then. There are apparently still arrears from certain public entities outside the core government sector, including some municipalities, and Electra has become more active in addressing these problems (including by shutting off supplies to non-payers).

A successful outcome in the current negotiations between the government and Electra-through independent arbitration if necessary - is essential in order to rectify the legacy of difficulties that has arisen in this area and to place Electra on a surer financing footing to meet its key investment requirements. Furthermore, a vital step in preventing a recurrence of these difficulties is for an automatic and transparent mechanism to be adopted to adjust electricity and water tariffs based on changes in input costs. Under the program, the Economic Regulation Agency (ARE) is to approve such a mechanism by December 2004. 
15. The national airline (TACV) is being prepared for privatization in 2006, following the appointment of a new management team in January 2005 to restructure the company and streamline its operations. TACV's financial performance has improved over the past year. Operating losses have been reduced and the company is meeting its current obligations, including to the airport and air navigation authority (ASA) for operating expenses and passenger fees.

\section{The government has submitted a proposal for funding from the Millennium}

Challenge Account (MCA). This proposal, amounting to about US\$75 million, is designed to support rural development, including improvements in water supply and infrastructure, and to strengthen competitiveness by lowering energy costs, increasing skill levels, and promoting diversification.

\section{The government has recently completed its Poverty Reduction Strategy Paper}

(PRSP), and the IMF and World Bank staffs have prepared a Joint Staff Advisory Note on this paper (see below).

\section{REPORT ON THE DISCUSSIONS}

18. Discussions with the authorities focused on:

- $\quad$ The macroeconomic framework for the remainder of 2004 and for 2005;

- $\quad$ Fiscal and monetary policies to achieve the international reserve accumulation target;

- Implementation of structural reforms to strengthen public enterprises and enhance international competitiveness;

- $\quad$ Progress in implementing the PRSP;

- $\quad$ General features of a successor arrangement.

\section{A. Macroeconomic Framework for the Remainder of 2004 and for 2005}

19. The Cape Verdean authorities confirmed their commitment to maintain a fiscal and monetary stance that supports macroeconomic stability and the credibility of the exchange rate peg. Among the indicative targets set for the end of 2005, the authorities agreed to a further increase in international reserve coverage: this is forecast to increase from 2.2 months of imports in 2004 to 2.4 months in 2005, an increase equivalent to over 2 percent of GDP. Discussions also assessed the prospects for an acceleration of growth in the period ahead. Given the strong outlook for private and public investment (discussed below), real GDP growth is expected to pick up to 6 percent in 2005, while inflation is projected to remain low. Growth of money and credit would remain consistent with the increase in nominal GDP and the targeted growth of international reserves. The program is fully financed through the end of the current PRGF arrangement.

20. The pickup in GDP growth projected for 2005 reflects in large part the impact of several important private and public investment projects. In particular: 
- New international airports are scheduled to be completed in Praia in early-2005 and in Boa Vista in early-2006, and the airport in Sao Vicente will be upgraded to accommodate international air traffic by early-2006. These publicly funded projects are aimed at improving international air access to the different islands and at lowering inter-island costs of travel and transport - including in support of tourism and island development more generally.

- A major hotel is to be completed on Sal for the 2005 tourist season, and construction of several hotels - set to open in 2006 - will also be under way on Boa Vista. These hotels are privately funded, including foreign participation.

- $\quad$ A new privately funded cement factory should be completed by January 2006, which will reduce the cost of construction materials.

- New foreign investment has also been attracted to the commercial fishing sector, reflecting the improved outlook for this sector following the repeal of a European Union embargo on fish imports from Cape Verde.

\section{B. Fiscal Policy}

21. The mission reached agreement with the authorities on a fiscal stance for 2005 that includes ongoing restraint of recurrent spending, growth of tax revenues in line with increases in nominal activity, and further improvements in tax administration (including two additional structural benchmarks to be met over the next 3 months). As a result, the recurrent primary domestic surplus is projected to be 5.0 percent of GDP in 2005, up from the surplus of 4.5 percent of GDP now expected in 2004 (and 2.6 percent of GDP in the 2004 program). With public investment largely determined by the availability of external financing, the overall deficit (including grants) is projected to be 3.7 percent of GDP in 2005.

\section{The 2005 budget passed by the National Assembly incorporates recommendations} the staff had provided on an earlier draft of this law. The budget strikes a balance between the authorities' desire to move ahead with priority spending, and the need to ensure that fiscal policy supports the targeted increase in net international reserves and adequate growth in credit to the private sector.

\section{The mission reiterated its view that recurrent expenditures need to be contained.}

The authorities agreed with this assessment and reaffirmed their commitment to ensuring that the pace of implementing their poverty reduction strategy remains fully consistent with continued macroeconomic stability. After growing by 15 percent in 2004, the nominal wage bill will increase by under 3 percent in 2005-implying that the wage bill would decline by about 0.8 percent of GDP. ${ }^{3}$ This moderation reflects the containment of new hiring, which has

\footnotetext{
${ }^{3}$ The strong growth of the wage bill in 2004 reflects in part an increase in the number of teachers as a result of the government's decision in 2001 to raise the minimum number of years of compulsory education from four to six.
} 
increased substantially over recent years, coupled with salary increases that are in line with the low rate of inflation.

\section{The authorities intend to push ahead with fiscal reforms to strengthen revenue} performance. Substantial progress has been made over recent years in modernizing the tax system and, as noted by a recent FAD technical assistance mission, Cape Verde now has a rational and modern tax system. However, further efforts are needed to improve tax administration and to consolidate the successful results to date of the new VAT. In this regard, the authorities are implementing a strategy to strengthen the organization and operations of the revenue authority (DGCI). In addition, drawing on the results of the FAD mission, agreement was reached on two additional benchmarks for the remainder of the program to improve administration of the VAT (see Box 2 and paragraph 14 of the MEFP).

\section{Box 2. Structural Conditionality}

Status and coverage of structural conditionality under the PRGF-supported program: As set out when the PRGF-supported program was launched in April 2002 (see www.imf.org), structural measures throughout the program have aimed at strengthening monetary policy, improving fiscal stability and transparency, strengthening the tax system, and reducing budgetary subsidies to public and private enterprises.

Compliance with structural conditions as set out during the $4^{\text {th }}$ Review (see MEFP, Table 2): The authorities met all continuous structural performance criteria. Most structural benchmarks were also met, and of the three that were not, the assessment of tax exemptions (for June 2004) has recently been conducted, and the authorities are making progress toward complying with the remaining two.

Remaining structural performance criteria (see MEFP, Table 3): The government is committed to: (i) refraining from providing budgetary subsidy to Electra for current operating expenses (continuous); (ii) refraining from providing budgetary subsidy to TACV for current operating expenses (continuous); (iii) approving, by the Board of ARE, an automatic and transparent mechanism for adjusting electricity and water tariffs on the basis of costs, and publishing this mechanism in the official gazette (end-December 2004). Structural performance benchmarks include (i) presenting a budget incorporating reductions of tax exemptions to the National Assembly (end-December 2004); (ii) introducing all VAT returns into the VAT computer system (end-December 2004); and, (iii) implementing new rules for tax collections through commercial banks (end-February 2005). The last two items were introduced as part of the $5^{\text {th }}$ review of the program.

Structural areas covered by World Bank lending and conditionality: The World Bank is supporting reform of public service enterprises, as well as improvements in related areas, through a Privatization and Regulation Project and a Growth and Competitiveness Project. A Poverty Reduction Support Credit is being prepared, but the associated conditionality has not yet been established. 


\section{Monetary Policy}

25. The monetary program for $\mathbf{2 0 0 5}$ is designed to support ongoing price stability and the accumulation of international reserves. With money demand assumed to rise in line with nominal GDP, growth of bank credit to the government would be limited to 0.1 percent in 2005 in order to support the increase in reserve coverage and adequate growth of credit to the economy. Within the scope provided by the reserve target, the BCV will continue pursuing measures to support reductions in commercial lending rates, including through encouraging increased competition in the banking sector and assessing the scope for reducing unremunerated reserve requirements.

\section{Commercial banks fully comply with prudential regulations. However, potential} concerns of the BCV include the high concentration of credit, the need for alternative sources of bank financing, and the oligopolistic behavior of the two largest banks in setting interest rates. The BCV also has some concerns about excess liquidity in the commercial banking system. To address these concerns, the $\mathrm{BCV}$ is working on introducing a broader variety of indirect monetary policy instruments to improve liquidity management.

\section{Structural Reforms}

27. The government's structural reform agenda is focused on promoting private sector-led growth, and reducing poverty and inequality. Key components of this strategy involve:

- $\quad$ developing domestic infrastructure, including ports and airports;

- $\quad$ attracting foreign investment to support tourism growth and development of other sectors, in part through measures to improve the business climate and strengthen competition;

- $\quad$ reforming large public service enterprises that are either owned or regulated by the state;

- $\quad$ regularizing the public sector's financial relations with major enterprises and utilities (see paragraphs $18-21$ of the MEFP).

28. The privatization process is being accompanied by the development of associated regulatory capacity. With the privatization and concessioning of remaining port operations set to be completed by mid-2005, the national port authority (ENAPOR) will be converted into a regulatory agency for the maritime sector. As discussed above, the Economic Regulation Authority is responsible for implementing mechanisms to set fuel, electricity, and water tariffs. Other sector specific regulatory agencies are also being developed, including in the pharmaceutical industry. Discussions are continuing on the most appropriate model for administering the various regulatory bodies, but this issue is not expected to delay completion of the privatization process. 


\section{E. The Poverty Reduction Strategy Paper}

\section{In the Joint Staff Advisory Note (JSAN) on the PRSP, the IMF and World Bank} staffs conclude that the PRSP provides an appropriate framework for addressing Cape Verde's development challenges. The JSAN will be discussed by the IMF Board on the same date as the current staff report. Given the strong investment growth projected in the PRSP, the JSAN emphasizes the need for the authorities to make ongoing efforts to attract external grants and concessional financing; to improve domestic resource mobilization, backed by further improvements in public administration; and to strengthen prioritization among the PRSP's wideranging objectives, including through implementation of the medium-term expenditure framework that is currently being developed. These points were discussed with and accepted by the authorities, including the PRSP steering committee. The authorities agreed that for short-term planning purposes, including in the PRGF-supported program, more conservative assumptions for investment growth and donor support should be applied. The authorities also indicated that they intend to organize a donors' conference in the first half of 2005 and, as noted above, they are finalizing a proposal for around US\$75 million in funding from the Millennium Challenge Account.

30. While recognizing the significant progress that Cape Verde has made in improving economic and social conditions, the JSAN notes the need for ongoing reforms both to accommodate the growing demands for and costs of social services, and to improve the climate for private-sector-led growth. For example, the staffs recommend that new sources of financing be identified to support increased education spending; that health policy place particular attention on preventative care; and that reform proposals for the non-contributory pension system be implemented. As discussed above, progress is being made in some areas identified in the JSAN as necessary to improve the business climate, including through improvements in infrastructure and completion of the privatization program. Nevertheless, the staffs urge that the PRSP's ambitious development plans for sea and air transport be implemented cautiously, with further clarification regarding the involvement of private partners, to reduce the risk of the government incurring significant contingent liabilities in these areas.

\section{Discussion of a SucCessor Program}

\section{In the Letter of Intent, the authorities reiterate their desire to maintain a strong} working relationship with the Fund after the current PRGF arrangement comes to an end. In this regard, the staff will discuss with the government the possibility of moving to a lowaccess PRGF. Such an arrangement would give due recognition to the authorities' sound economic management over recent years, provide a solid framework for ongoing macroeconomic stability throughout 2005 and beyond, and reassure donors of the Fund's continuing close surveillance of economic and policy developments. The authorities fully agree with the staff that debt sustainability should continue to be a central feature of any new arrangement. A full debt sustainability analysis will be conducted as part of the forthcoming Article IV consultation. 


\section{Statistical IsSUES}

32. Some statistical systems remain weak, especially in the real sector, although data have been generally adequate to enable monitoring of the program. Several recent or prospective developments will support efforts to address areas of weaknesses. In particular, the National Statistics Institute (INE) will issue final national accounts data for 2001 and 2002 in early 2005; will present an updated CPI methodology in 2005; has recently developed a set of confidence indicators to provide a more contemporaneous view of business sentiment and activity; and is working on the development of quarterly national accounts. INE is obtaining technical assistance from the Fund, including in the context of the GDDS project for Lusophone Countries.

\section{Staff Appraisal}

\section{Cape Verde's economic and policy performance under the PRGF-supported} program remains on track. The government is appropriately focused on maintaining macroeconomic stability and executing a prudent social and economic reform agenda aimed at reducing poverty. Notwithstanding higher international oil prices, the fiscal and NIR targets for this review have been met with clear margins, growth appears strong and robust, and inflation remains low.

\section{Substantial progress on structural reforms, following some loss of momentum in} early 2004, has also helped to support economic prospects and confidence. All structural performance criteria have been observed. Of the three structural benchmarks that were missed, one has since been met, one is scheduled for completion by end-December 2004, and negotiations surrounding the remaining benchmark (an assessment of the government's liabilities to the power and water company) are now under way.

\section{The authorities are to be commended for their successes, but there remains little} room for complacency. On the macroeconomic front, the authorities need to resist pressures for higher spending ahead of the January 2006 parliamentary elections, particularly in order to avoid a repetition of the setbacks experienced during previous electoral campaigns. Renewed efforts to rein in tax exemptions are important, as are further reforms to tax administration-including measures to strengthen the new VAT. As for monetary policy, the authorities need to ensure that money and credit growth remain consistent with ongoing low inflation, expected growth in real activity, and the targeted increase in international reserve coverage.

\section{To maintain the strength of Cape Verde's macroeconomic performance, further} progress with structural reforms is also needed. A key issue in this regard is for the government to regularize its financial relations with Electra, drawing on negotiation and arbitration as appropriate. In addition to settling past public obligations to Electra, a vital step to avert a recurrence of these problems is the adoption by the Economic Regulatory Agency of an automatic and transparent mechanism to set electricity and water tariffs. Failure to address such issues could hamper energy sector development and overall growth prospects, and create substantial fiscal risks. 
37. The government should move ahead vigorously with its plans to restructure and sell the remaining enterprises on its privatization agenda. Also essential in this regard is the development of associated regulatory institutions and capacities to ensure that competition and service quality will be secured.

38. The PRSP provides an important framework for the authorities' efforts to reduce poverty and raise growth levels to the targeted 6 to 7 percent range. As they begin implementing the poverty reduction strategy, the authorities will need to maintain a clear sense of priorities in order to ensure the quality of programs and policies. Furthermore, the staff urges that, in implementing the PRSP, the authorities continue to emphasize the importance of maintaining macroeconomic stability and debt sustainability.

39. On the strength of the policies being pursued by the authorities, as well as their commendable track record with respect to policy implementation, the staff recommends the completion of the fifth review under the PRGF arrangement. The staff also recommends approval of the authorities' request for a short extension of the arrangement to end-July, 2005. 
Figure 1. Cape Verde: Selected Economic Indicators, 1995-2004 ${ }^{1}$
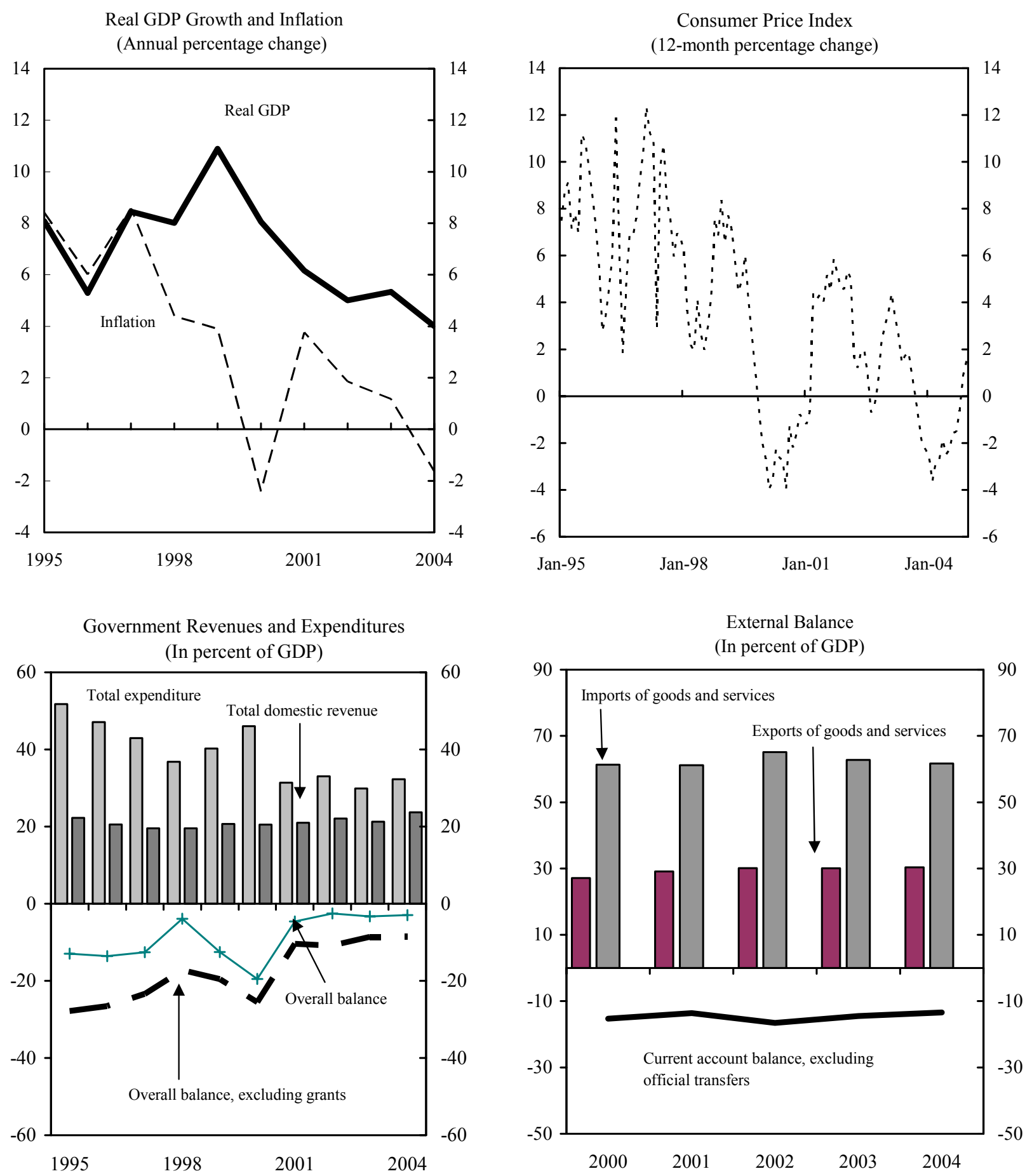

Sources: Cape Verdean authorities; and Fund staff estimates and projections.

1/ Data for 2004 are projections. 
Figure 2. Cape Verde: Real and Nominal Effective Exchange Rates, January 1995-August 2004

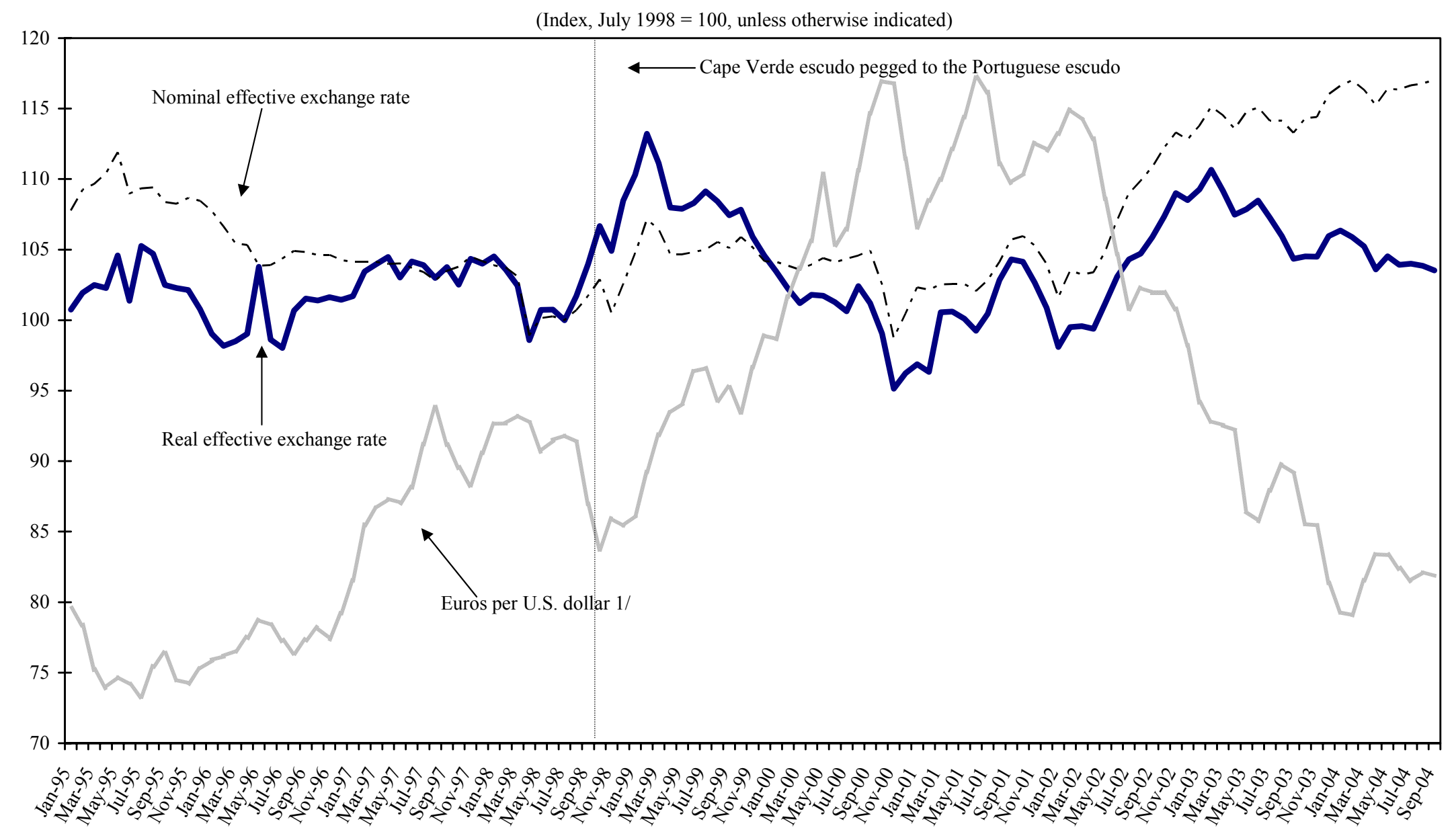

Source: International Monetary Fund, Information Notice System (INS).

1/ Prior to January 1999, based on the Portuguese escudo multiplied by the December 1998 euro-escudo conversion rate. 
Figure 3. Cape Verde: Monetary Indicators, January 2000-April 2004 (In percent, unless otherwise indicated)

Net International Reserves

(In millions of euros)

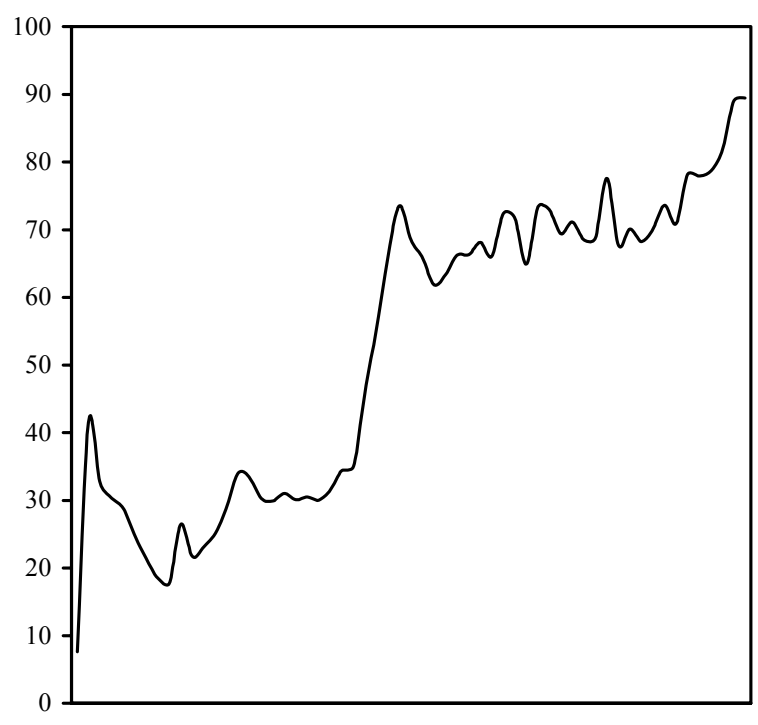

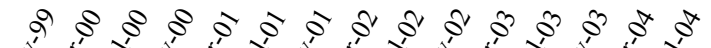
bi

Excess Liquidity in the Banking System

(As a percent of broad money)

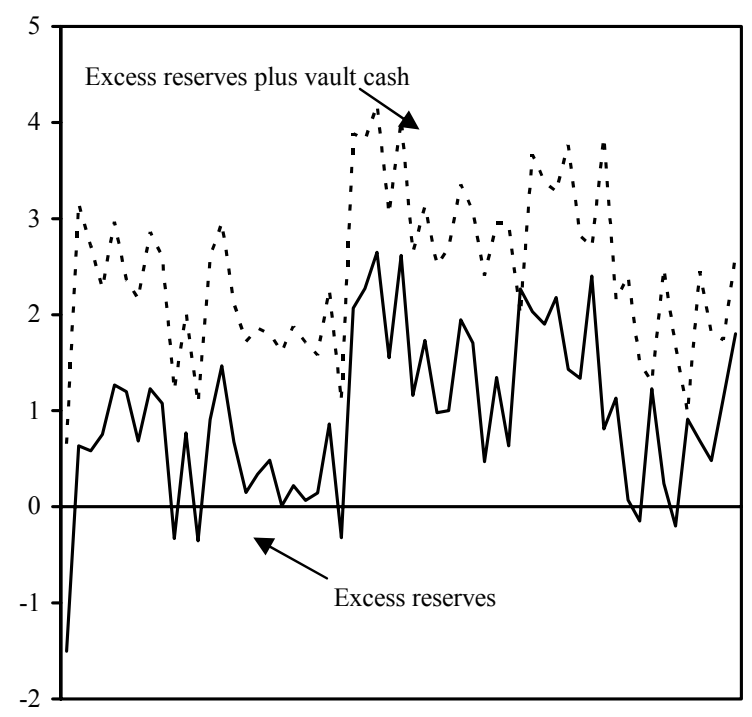

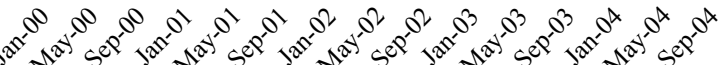

Contribution to Broad Money Growth (Change in percent of broad money 12 months earlier)

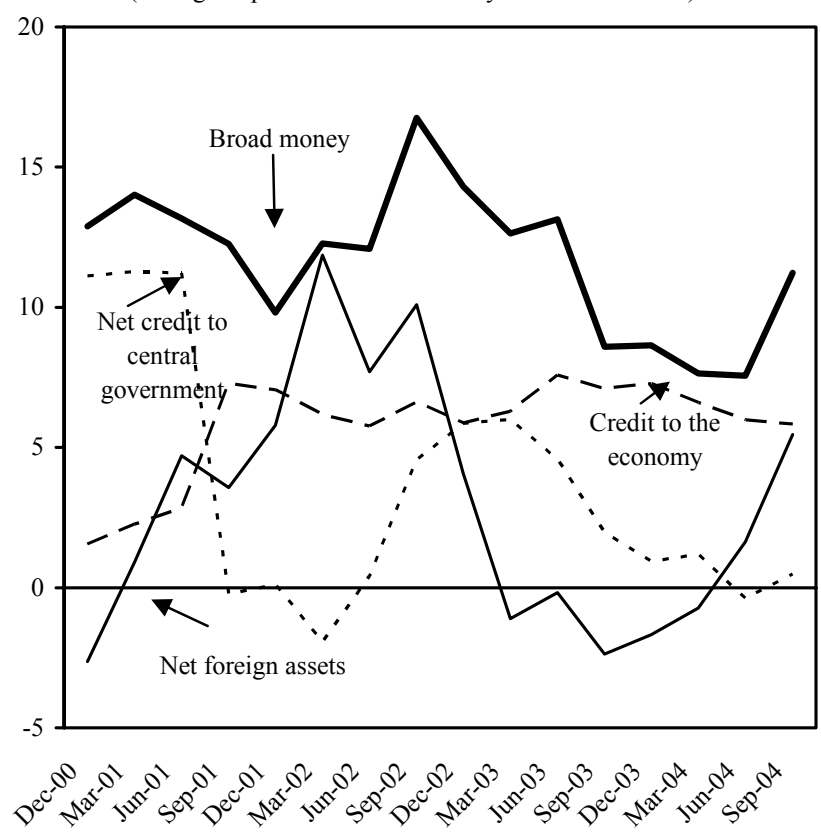

Selected Interest Rates

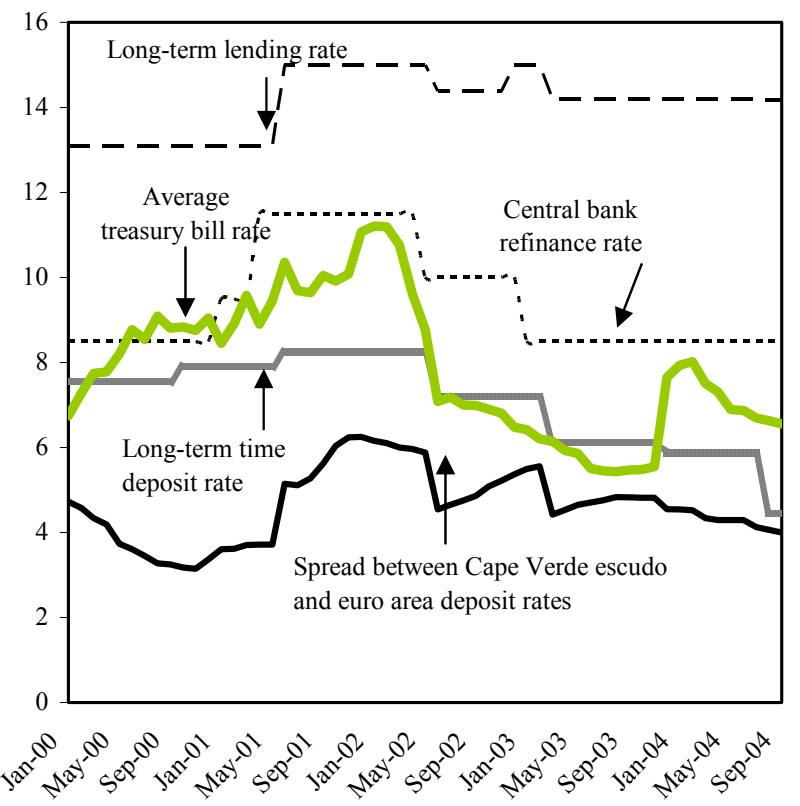

Sources: Bank of Cape Verde; IMF, International Financial Statistics; and Fund staff estimates. 
Table 1. Cape Verde: Selected Economic and Financial Indicators, 2001-05

\begin{tabular}{|c|c|c|c|c|c|c|c|}
\hline & \multirow[t]{2}{*}{2001} & \multirow[t]{2}{*}{2002} & \multicolumn{2}{|c|}{2003} & \multicolumn{2}{|c|}{2004} & \multirow{2}{*}{$\begin{array}{l}2005 \\
\text { Proj. }\end{array}$} \\
\hline & & & Program 1/ & Prel. & Program 1/ & Rev. Proj. & \\
\hline & \multicolumn{6}{|c|}{ (Annual percentage change) } & \\
\hline \multicolumn{8}{|l|}{ National income and prices } \\
\hline Real GDP & 6.2 & 5.0 & 5.0 & 5.3 & 5.0 & 4.0 & 6.0 \\
\hline Real GDP (per capita) & 4.3 & 3.1 & 3.1 & 3.4 & 3.1 & 2.1 & 4.6 \\
\hline Consumer price index (annual average) & 3.8 & 1.8 & 2.3 & 1.2 & 2.0 & -1.6 & 2.0 \\
\hline Consumer price index (end of period) & 4.6 & 3.0 & 2.0 & -2.3 & 2.0 & 1.5 & 1.0 \\
\hline \multicolumn{8}{|l|}{ External sector } \\
\hline Exports (in euros) $2 /$ & 17.5 & 10.5 & 4.1 & 8.9 & 9.0 & 6.1 & 9.5 \\
\hline Imports (in euros) 2/ & 9.2 & 13.8 & 5.2 & 5.1 & 6.1 & 3.3 & 9.2 \\
\hline Real effective exchange rate (annual average) & 0.2 & 2.6 & $\ldots$ & 3.4 & $\ldots$ & $\ldots$ & $\ldots$ \\
\hline Terms of trade (minus $=$ deterioration) & 0.5 & -0.9 & 2.0 & 1.8 & 1.1 & -3.2 & 1.1 \\
\hline \multicolumn{8}{|l|}{ Government budget } \\
\hline Total revenue (excluding grants) & 12.1 & 12.3 & 2.2 & 5.1 & 4.6 & 17.1 & 9.6 \\
\hline Total expenditure & -25.4 & 12.2 & 6.7 & -1.2 & 6.2 & 13.5 & 7.0 \\
\hline Recurrent and extraordinary expenditure & -31.2 & 3.0 & 8.6 & 6.4 & 9.9 & 13.4 & 4.7 \\
\hline Capital expenditure & -9.6 & 27.8 & -0.4 & -18.0 & 4.5 & 17.9 & 16.3 \\
\hline & \multicolumn{7}{|c|}{ (Annual change in percent of beginning-of-period broad money, unless otherwise indicated) } \\
\hline \multicolumn{8}{|l|}{ Money and credit } \\
\hline Net domestic assets & 4.0 & 10.5 & 7.5 & 10.3 & 6.2 & 5.5 & 5.7 \\
\hline Of which: net claims on the central government & 0.1 & 5.9 & 1.6 & 0.9 & 0.0 & 0.7 & 0.2 \\
\hline credit to the economy & 7.1 & 5.9 & 6.1 & 7.3 & 6.2 & 5.3 & 3.7 \\
\hline Broad money (M2) & 9.8 & 14.3 & 7.8 & 8.6 & 8.2 & 8.2 & 8.6 \\
\hline Domestic broad money (M2X) & 3.4 & 10.3 & $\ldots$ & 4.2 & $\ldots$ & 6.7 & 8.2 \\
\hline Income velocity (GDP/M2) & 1.61 & 1.54 & 1.49 & 1.51 & 1.49 & 1.46 & 1.48 \\
\hline \multicolumn{8}{|c|}{ (In percent of GDP) } \\
\hline Saving-investment balance & & & & & & & \\
\hline Gross domestic investment & 18.3 & 21.4 & 19.8 & 18.2 & 19.6 & 17.4 & 17.6 \\
\hline Public & 5.2 & 6.2 & 5.7 & 4.7 & 5.6 & 5.2 & 5.5 \\
\hline Private & 13.1 & 15.2 & 14.0 & 13.5 & 14.1 & 12.2 & 12.1 \\
\hline Gross national savings & 8.4 & 10.4 & 9.4 & 9.0 & 9.2 & 9.6 & 9.4 \\
\hline Of which: public sector & 5.4 & 9.6 & 6.7 & 5.4 & 5.2 & 7.2 & 7.1 \\
\hline External current account (including official transfers) & -9.9 & -11.0 & -10.3 & -9.2 & -10.5 & -7.8 & -8.2 \\
\hline \multicolumn{8}{|l|}{ Government budget } \\
\hline Total revenue & 21.0 & 22.1 & 21.7 & 21.3 & 21.0 & 23.7 & 23.7 \\
\hline Total grants & 5.8 & 8.4 & 7.0 & 5.3 & 5.6 & 5.6 & 4.1 \\
\hline Total expenditure & 31.4 & 33.0 & 32.7 & 29.9 & 32.2 & 32.3 & 31.5 \\
\hline Overall balance (including grants) & -4.6 & -2.5 & -4.1 & -3.2 & -5.6 & -2.9 & -3.7 \\
\hline Domestic bank financing & 0.1 & 3.6 & 1.0 & 1.1 & 0.0 & 0.6 & 0.0 \\
\hline Total public debt $3 /$ & 91.2 & 84.4 & 81.6 & 73.7 & 80.2 & 74.7 & 70.3 \\
\hline External public debt 4 / & 62.4 & 54.4 & 53.5 & 44.9 & 53.8 & 47.6 & 45.8 \\
\hline Domestic public debt 5/ & 28.8 & 30.0 & 28.1 & 28.8 & 26.4 & 27.1 & 24.5 \\
\hline External current account (excluding official transfers) & -13.6 & -16.5 & -17.3 & -14.5 & -16.1 & -13.4 & -12.3 \\
\hline Overall balance of payments & 2.7 & 3.6 & 0.8 & -0.6 & -2.0 & 1.3 & 1.8 \\
\hline \multicolumn{8}{|c|}{ (In units specified) } \\
\hline External current account (million euros, including official transfers) & -63.6 & -75.4 & -76.1 & -68.3 & -87.3 & -61.2 & -70.9 \\
\hline Gross international reserves (million euros, end of period) & 47.5 & 76.1 & 86.2 & 74.1 & 104.3 & 87.4 & 105.6 \\
\hline \multicolumn{8}{|l|}{ Gross international reserves (in months } \\
\hline of imports of goods and services) & 1.5 & 2.0 & 2.2 & 1.9 & 2.4 & 2.2 & 2.4 \\
\hline \multicolumn{8}{|l|}{ External debt service (in percent of exports } \\
\hline of goods and nonfactor services) & 29.2 & 15.6 & 11.5 & 10.6 & 12.4 & 11.2 & 9.2 \\
\hline \multicolumn{8}{|l|}{ Memorandum items: } \\
\hline Nominal GDP (in billions of Cape Verde escudos) & 70.6 & 75.5 & 81.2 & 82.3 & 87.5 & 86.5 & 94.8 \\
\hline Exchange rate (Cape Verde escudos per U.S. dollar) & & & & & & & \\
\hline Period average & 123.2 & 117.2 & $\ldots$ & 97.7 & $\ldots$ & 89.8 & $\ldots$ \\
\hline End period & 125.1 & 105.1 & $\ldots$ & 87.3 & $\ldots$ & 90.5 & $\ldots$ \\
\hline
\end{tabular}

Sources: Cape Verdean authorities; and staff estimates and projections.

1/ As contained in the August 6, 2004 staff report (IMF Country Report 04/304).

2/ Exports and imports of goods and nonfactor services.

3/ Including verified stock of domestic and external arrears.

4/ Projection numbers include financing gap.

5/ Excluding the claims on the offshore Trust Fund. 
Table 2. Cape Verde: Annual Fiscal Operations of the Central Government, 2001-05

\begin{tabular}{|c|c|c|c|c|c|c|c|}
\hline & \multirow[t]{2}{*}{2001} & \multirow[t]{2}{*}{2002} & \multicolumn{2}{|c|}{2003} & \multicolumn{2}{|c|}{2004} & \multirow{2}{*}{$\begin{array}{c}2005 \\
\text { Proj. }\end{array}$} \\
\hline & & & Program 1/ & Prel. & Program 1/ & Rev. Proj. & \\
\hline & \multicolumn{6}{|c|}{ (In billions of Cape Verde escudos, unless otherwise indicated) } & \\
\hline Revenue, grants, and net lending & 18.9 & 23.0 & 23.2 & 21.9 & 23.3 & 25.4 & 26.3 \\
\hline Domestic revenue & 14.8 & 16.7 & 17.6 & 17.5 & 18.4 & 20.5 & 22.5 \\
\hline Tax revenue $2 /$ & 13.0 & 14.7 & 15.7 & 15.5 & 16.6 & 18.2 & 20.0 \\
\hline Income and profit taxes & 4.8 & 5.1 & 5.5 & 5.3 & 6.1 & 6.7 & 6.9 \\
\hline Consumption taxes & 2.1 & 2.5 & 2.5 & 2.5 & 2.7 & 6.9 & 7.9 \\
\hline Taxes on goods and services & 2.1 & 2.5 & & 2.5 & & 1.2 & 1.3 \\
\hline of which: petroleum taxes & 0.1 & 0.3 & & 0.2 & & 0.4 & 0.4 \\
\hline Value-added tax & 0.0 & 0.0 & & 0.0 & & 5.7 & 6.5 \\
\hline International trade taxes $2 /$ & 5.3 & 6.1 & 6.8 & 6.8 & 6.8 & 3.7 & 4.2 \\
\hline Other taxes & 0.8 & 0.9 & 0.9 & 0.9 & 0.9 & 0.9 & 1.1 \\
\hline Nontax revenue & 1.5 & 1.8 & 1.3 & 1.5 & 1.6 & 2.0 & 2.2 \\
\hline Domestic capital participation & 0.0 & 0.0 & 0.0 & 0.0 & 0.0 & 0.0 & 0.0 \\
\hline Net lending & 0.3 & 0.2 & 0.6 & 0.5 & 0.3 & 0.3 & 0.2 \\
\hline External grants & 4.1 & 6.3 & 5.7 & 4.4 & 4.9 & 4.9 & 3.9 \\
\hline Capital grants & 4.1 & 5.2 & 4.9 & 3.6 & 4.9 & 3.7 & 3.1 \\
\hline Budget support & 0.0 & 1.2 & 0.8 & 0.8 & 0.0 & 1.1 & 0.8 \\
\hline Total expenditure & 22.2 & 24.9 & 26.6 & 24.6 & 28.2 & 27.9 & 29.9 \\
\hline Recurrent expenditure & 14.9 & 15.3 & 16.6 & 16.3 & 18.3 & 18.5 & 19.3 \\
\hline Primary recurrent expenditure & 13.4 & 13.3 & 14.5 & 14.3 & 16.1 & 16.6 & 17.7 \\
\hline Wages and salaries & 6.6 & 7.1 & 8.5 & 9.4 & 9.3 & 10.8 & 11.1 \\
\hline Goods and services & 0.6 & 0.6 & 1.5 & 1.3 & 1.7 & 1.7 & 1.7 \\
\hline Transfers and subsidies & 5.7 & 4.9 & 3.9 & 2.8 & 4.4 & 3.2 & 3.6 \\
\hline Other expenditures & 0.5 & 0.7 & 0.6 & 0.8 & 0.8 & 1.0 & 1.3 \\
\hline Domestic interest payments & 0.9 & 1.4 & 1.5 & 1.5 & 1.6 & 1.3 & 1.1 \\
\hline External interest payments & 0.6 & 0.6 & 0.6 & 0.5 & 0.6 & 0.6 & 0.6 \\
\hline Extraordinary expenditures & 0.0 & 0.2 & 0.6 & 0.6 & 0.2 & 0.4 & 0.0 \\
\hline Capital expenditure & 7.3 & 9.4 & 9.3 & 7.7 & 9.7 & 9.0 & 10.5 \\
\hline Foreign financed & 6.2 & 8.6 & 8.5 & 6.9 & 8.7 & 8.0 & 9.0 \\
\hline Domestically financed & 1.1 & 0.7 & 0.8 & 0.8 & 1.0 & 1.0 & 1.5 \\
\hline Overall balance, including grants 3 / & -3.2 & -1.9 & -3.3 & -2.7 & -4.9 & -2.5 & -3.5 \\
\hline Financing & 3.0 & 1.4 & 3.3 & 3.0 & 2.1 & 2.6 & 2.2 \\
\hline Foreign (net) & 2.1 & 1.1 & 3.2 & 2.0 & 1.8 & 2.8 & 2.4 \\
\hline Total drawings & 7.6 & 4.1 & 5.3 & 4.1 & 4.4 & 5.2 & 4.5 \\
\hline Balance of payments, budget & 5.1 & 1.3 & 1.7 & 1.3 & 0.6 & 0.9 & 2.2 \\
\hline Project loans & 2.5 & 2.8 & 3.6 & 2.8 & 3.8 & 4.3 & 2.3 \\
\hline Amortization & -5.4 & -3.0 & -2.1 & -2.1 & -2.6 & -2.4 & -2.1 \\
\hline Domestic (net) & 0.9 & 0.2 & 0.2 & 1.0 & 0.3 & -0.2 & -0.2 \\
\hline Banking system & 0.1 & 2.7 & 0.8 & 0.9 & 0.0 & 0.6 & 0.0 \\
\hline Nonbanks & 1.3 & 1.5 & 0.4 & 0.7 & 0.3 & 0.3 & 0.3 \\
\hline Domestic arrears 2/ & -0.5 & -3.9 & -1.0 & -0.6 & 0.0 & -1.1 & -0.5 \\
\hline Net errors and omissions & 0.2 & 0.5 & 0.0 & -0.4 & 0.0 & -0.1 & 0.0 \\
\hline Financing gap & 0.0 & 0.0 & 0.0 & 0.0 & 2.9 & 0.0 & 1.3 \\
\hline Identified possible financing & $\ldots$ & $\ldots$ & $\ldots$ & $\ldots$ & 2.2 & 0.0 & 1.3 \\
\hline Netherlands & $\ldots$ & $\ldots$ & $\ldots$ & $\ldots$ & 0.3 & 0.0 & 0.0 \\
\hline European Union & $\ldots$ & $\ldots$ & $\ldots$ & $\ldots$ & 0.7 & 0.0 & 1.3 \\
\hline African Development Bank & $\ldots$ & $\ldots$ & $\ldots$ & $\ldots$ & 0.3 & 0.0 & 0.0 \\
\hline World Bank & $\ldots$ & $\ldots$ & $\ldots$ & $\ldots$ & 0.9 & 0.0 & 0.0 \\
\hline Residual financing gap & $\cdots$ & $\cdots$ & $\cdots$ & $\cdots$ & 0.6 & 0.0 & 0.0 \\
\hline \multicolumn{8}{|l|}{ Memorandum items: } \\
\hline Domestic expenditures 4/ & 15.4 & 15.7 & 17.5 & 17.2 & 18.9 & 19.3 & 20.3 \\
\hline Domestic balance 5/ & -0.6 & 1.0 & 0.1 & 0.4 & -0.5 & 1.2 & 2.2 \\
\hline Primary domestic balance $6 /$ & 0.3 & 2.4 & 1.6 & 1.8 & 1.1 & 2.5 & 3.3 \\
\hline Primary recurrent domestic balance $7 /$ & 1.5 & 3.3 & 3.1 & 3.2 & 2.3 & 3.9 & 4.8 \\
\hline Overall balance, excluding grants $8 /$ & -7.4 & -8.2 & -9.0 & -7.1 & -9.8 & -7.4 & -7.4 \\
\hline Net external flows $9 /$ & 6.2 & 7.5 & 8.8 & 6.4 & 9.5 & 7.7 & 7.6 \\
\hline External debt service (in percent of domestic revenue) & 40.5 & 21.3 & 15.4 & 14.9 & 17.3 & 14.3 & 11.7 \\
\hline Tax and non-tax arrears $10 /$ & $\ldots$ & $\ldots$ & $\ldots$ & 0.5 & $\ldots$ & 0.8 & $\ldots$ \\
\hline
\end{tabular}


Table 2. Cape Verde: Annual Fiscal Operations of the Central Government, 2001-05 (concluded)

\begin{tabular}{|c|c|c|c|c|c|c|c|}
\hline & \multirow[t]{2}{*}{2001} & \multirow[t]{2}{*}{2002} & \multicolumn{2}{|c|}{2003} & \multicolumn{2}{|c|}{2004} & \multirow{2}{*}{$\begin{array}{l}2005 \\
\text { Proj. }\end{array}$} \\
\hline & & & Program 1/ & Prel. & Program 1/ & Rev. Proj. & \\
\hline & \multicolumn{6}{|c|}{ (In percent of GDP, unless otherwise indicated) } & \\
\hline Revenue, grants, and net lending & 26.8 & 30.5 & 28.6 & 26.6 & 26.6 & 29.3 & 27.8 \\
\hline Domestic revenue & 21.0 & 22.1 & 21.7 & 21.3 & 21.0 & 23.7 & 23.7 \\
\hline Tax revenue $2 /$ & 18.4 & 19.5 & 19.3 & 18.8 & 18.9 & 21.1 & 21.1 \\
\hline Income and profit taxes & 6.8 & 6.8 & 6.8 & 6.4 & 7.0 & 7.7 & 7.3 \\
\hline Consumption taxes & 3.0 & 3.3 & 3.1 & 3.0 & 3.1 & 8.0 & 8.3 \\
\hline Taxes on goods and services & 3.0 & 3.3 & $\ldots$ & 3.0 & $\ldots$ & 1.4 & 1.4 \\
\hline Value-added tax & 0.0 & 0.0 & $\ldots$ & 0.0 & $\ldots$ & 6.6 & 6.9 \\
\hline International trade taxes $2 /$ & 7.6 & 8.1 & 8.4 & 8.2 & 7.8 & 4.3 & 4.4 \\
\hline Other taxes & 1.1 & 1.3 & 1.1 & 1.1 & 1.1 & 1.1 & 1.1 \\
\hline Nontax revenue & 2.2 & 2.3 & 1.6 & 1.8 & 1.8 & 2.3 & 2.3 \\
\hline Net lending & 0.4 & 0.3 & 0.7 & 0.7 & 0.3 & 0.3 & 0.3 \\
\hline External grants & 5.8 & 8.4 & 7.0 & 5.3 & 5.6 & 5.6 & 4.1 \\
\hline Capital grants & 5.8 & 6.8 & 6.0 & 4.4 & 5.6 & 4.3 & 3.3 \\
\hline Budget support & 0.0 & 1.5 & 0.9 & 0.9 & 0.0 & 1.3 & 0.8 \\
\hline Total expenditure & 31.4 & 33.0 & 32.7 & 29.9 & 32.2 & 32.3 & 31.5 \\
\hline Recurrent expenditure & 21.0 & 20.3 & 20.5 & 19.8 & 20.9 & 21.4 & 20.4 \\
\hline Primary recurrent expenditure & 18.9 & 17.6 & 17.9 & 17.4 & 18.4 & 19.2 & 18.6 \\
\hline Wages and salaries & 9.3 & 9.4 & 10.4 & 11.4 & 10.6 & 12.5 & 11.7 \\
\hline Goods and services & 0.8 & 0.8 & 1.9 & 1.6 & 1.9 & 1.9 & 1.8 \\
\hline Transfers and subsidies & 8.1 & 6.5 & 4.8 & 3.5 & 5.0 & 3.7 & 3.8 \\
\hline Other expenditures & 0.7 & 1.0 & 0.7 & 0.9 & 0.9 & 1.1 & 1.4 \\
\hline Domestic interest payments & 1.3 & 1.9 & 1.9 & 1.8 & 1.8 & 1.5 & 1.2 \\
\hline External interest payments & 0.8 & 0.7 & 0.7 & 0.6 & 0.7 & 0.6 & 0.6 \\
\hline Extraordinary expenditures & 0.0 & 0.3 & 0.8 & 0.8 & 0.3 & 0.5 & 0.0 \\
\hline Capital expenditure & 10.4 & 12.4 & 11.5 & 9.3 & 11.1 & 10.5 & 11.1 \\
\hline Foreign financed & 8.8 & 11.4 & 10.5 & 8.4 & 10.0 & 9.3 & 9.5 \\
\hline Domestically financed & 1.6 & 1.0 & 1.0 & 0.9 & 1.2 & 1.2 & 1.6 \\
\hline Overall balance, including grants 3 / & -4.6 & -2.5 & -4.1 & -3.2 & -5.6 & -2.9 & -3.7 \\
\hline Financing & 4.2 & 1.8 & 4.1 & 3.7 & 2.4 & 3.0 & 2.3 \\
\hline Foreign (net) & 3.0 & 1.5 & 3.9 & 2.4 & 2.0 & 3.2 & 2.5 \\
\hline Total drawings & 10.7 & 5.5 & 6.5 & 5.0 & 5.0 & 6.0 & 4.7 \\
\hline Amortization & -7.7 & -4.0 & -2.6 & -2.6 & -3.0 & -2.7 & -2.2 \\
\hline Domestic (net) & 1.2 & 0.3 & 0.2 & 1.3 & 0.4 & -0.2 & -0.2 \\
\hline Banking system & 0.1 & 3.6 & 1.0 & 1.1 & 0.0 & 0.6 & 0.0 \\
\hline Nonbanks & 1.9 & 1.9 & 0.5 & 0.8 & 0.3 & 0.3 & 0.3 \\
\hline Domestic arrears 2/ & -0.7 & -5.2 & -1.3 & -0.7 & 0.0 & -1.2 & -0.5 \\
\hline Net errors and omissions & 0.4 & 0.7 & 0.0 & -0.4 & 0.0 & -0.1 & 0.0 \\
\hline Financing gap & 0.0 & 0.0 & 0.0 & 0.0 & 3.3 & 0.0 & 1.4 \\
\hline Identified possible financing & $\ldots$ & $\ldots$ & $\ldots$ & $\ldots$ & 2.6 & 0.0 & 1.4 \\
\hline Netherlands & $\ldots$ & $\ldots$ & $\ldots$ & $\ldots$ & 0.4 & 0.0 & 0.0 \\
\hline European Union & $\ldots$ & $\ldots$ & $\ldots$ & $\ldots$ & 0.8 & 0.0 & 1.4 \\
\hline African Development Bank & $\ldots$ & $\ldots$ & $\ldots$ & $\ldots$ & 0.4 & 0.0 & 0.0 \\
\hline World Bank & $\cdots$ & $\ldots$ & $\ldots$ & $\ldots$ & 1.1 & 0.0 & 0.0 \\
\hline Residual financing gap & $\ldots$ & $\ldots$ & $\ldots$ & $\ldots$ & 0.7 & 0.0 & 0.0 \\
\hline \multicolumn{8}{|l|}{ Memorandum items: } \\
\hline Domestic expenditures 4/ & 21.8 & 20.8 & 21.5 & 20.8 & 21.6 & 22.4 & 21.4 \\
\hline Domestic balance $5 /$ & -0.8 & 1.3 & 0.1 & 0.4 & -0.6 & 1.4 & 2.3 \\
\hline Primary domestic balance 6/ & 0.5 & 3.2 & 2.0 & 2.2 & 1.2 & 2.9 & 3.5 \\
\hline Primary recurrent domestic balance $7 /$ & 2.1 & 4.4 & 3.8 & 3.9 & 2.6 & 4.5 & 5.0 \\
\hline Overall balance, excluding grants 8 / & -10.4 & -10.9 & -11.0 & -8.6 & -11.2 & -8.6 & -7.8 \\
\hline Net external flows 9/ & 8.8 & 9.9 & 10.8 & 7.8 & 10.9 & 8.9 & 8.0 \\
\hline External debt service (in percent of domestic revenue) & 40.5 & 21.3 & 15.4 & 14.9 & 17.3 & 14.3 & 11.7 \\
\hline Tax and non-tax arrears $10 /$ & $\ldots$ & $\ldots$ & $\ldots$ & 0.6 & $\ldots$ & 0.9 & $\ldots$ \\
\hline
\end{tabular}

Sources: Ministry of Finance and Planning; Bank of Cape Verde; and staff estimates and projections.

1/ As contained in the August 6, 2004 staff report (IMF Country Report 04/304). Pensions in the program are classified as transfers, while in the budget and projections are classified as wages.

2/ 2003 includes exceptional revenues of CVEsc 455 million from old tax debt that were used to clear arrears of the same amount with a domestic oil company.

3/ "Overall balance, including grants" = revenue including grants - total expenditure.

4/ "Domestic expenditure" = total expenditure - external interest - foreign financed capital expenditure - capital expenditure financed by domestic capital participation.

5/ "Domestic balance" = domestic revenue - domestic expenditure.

6/ "Primary domestic balance" $=$ domestic revenue - domestic expenditure + domestic interest payments

7/ "Primary recurrent domestic balance"= domestic revenue - primary current expenditure.

8/ "Overall balance, excluding grants" = revenue excluding grants - total expenditure.

9/ Excluding external interest payments, and including financing gap.

10/ 2004 includes tax and non-tax arrears of CVEsc 803 million to clear arrears with Shell, Telecom, and construction companies. 
Table 3. Cape Verde: Monetary Survey, 2002-05

\begin{tabular}{|c|c|c|c|c|c|c|c|c|}
\hline & \multirow{3}{*}{$\frac{2002}{\text { Dec. }}$} & \multirow{3}{*}{$\begin{array}{l}2003 \\
\text { Dec. }\end{array}$} & \multicolumn{5}{|c|}{2004} & \multirow{3}{*}{$\begin{array}{l}2005 \\
\text { Dec. } \\
\text { Proj. }\end{array}$} \\
\hline & & & \multirow[t]{2}{*}{ March } & \multicolumn{2}{|c|}{ June } & \multirow{2}{*}{$\begin{array}{l}\text { Sep. } \\
\text { Prel. }\end{array}$} & \multirow{2}{*}{$\frac{\text { Dec. }}{\text { Rev.Proj. }}$} & \\
\hline & & & & Prog. & Actual & & & \\
\hline & \multicolumn{8}{|c|}{ (In millions of Cape Verde escudos, unless otherwise specified) } \\
\hline Net foreign assets & 11,331 & 10,456 & 11,169 & 11,706 & 11,593 & 13,515 & 11,992 & 13,748 \\
\hline Foreign assets & 13,841 & 13,434 & 14,138 & 14,933 & 14,559 & 16,825 & 15,433 & 17,798 \\
\hline Of which: foreign reserves & 8,391 & 8,173 & 8,479 & 9,273 & 9,321 & 10,673 & 9,641 & 11,644 \\
\hline Foreign liabilities & $-2,511$ & $-2,978$ & $-2,969$ & $-3,227$ & $-2,965$ & $-3,310$ & $-3,419$ & $-4,050$ \\
\hline Net domestic assets & 41,027 & 46,428 & 46,801 & 48,003 & 47,322 & 47,668 & 49,557 & 53,069 \\
\hline Net domestic credit & 49,916 & 54,503 & 54,903 & 56,113 & 55,173 & 56,493 & 58,637 & 60,636 \\
\hline Net claims on general government & 24,790 & 25,561 & 25,509 & 26,335 & 24,888 & 25,333 & 26,685 & 26,401 \\
\hline Claims on the Trust Fund (TCMFs) & 10,600 & 11,038 & 11,038 & 11,038 & 11,038 & 11,038 & 11,188 & 11,088 \\
\hline Net claims on the central government & 14,368 & 14,858 & 14,833 & 15,659 & 14,404 & 14,700 & 15,258 & 15,358 \\
\hline Credit to central government & 16,546 & 17,097 & 17,113 & 17,932 & 17,101 & 16,978 & 17,386 & 17,398 \\
\hline Deposits of central government & $-2,178$ & $-2,239$ & $-2,280$ & $-2,273$ & $-2,696$ & $-2,278$ & $-2,128$ & $-2,040$ \\
\hline Of which: project deposits & -397 & -393 & -351 & -351 & -983 & -287 & -287 & -237 \\
\hline Net claims on local government & 8 & 67 & 80 & 80 & 91 & 120 & 70 & 70 \\
\hline Net claims on other government agencies (INPS) & -186 & -402 & -442 & -442 & -646 & -524 & -124 & -114 \\
\hline Credit to the economy & 25,126 & 28,943 & 29,394 & 29,778 & 30,286 & 31,160 & 31,952 & 34,235 \\
\hline Credit to public enterprises & 230 & 180 & 167 & 167 & 183 & 161 & 196 & 208 \\
\hline Credit to private sector & 24,890 & 28,726 & 29,191 & 29,574 & 30,053 & 30,955 & 31,761 & 33,971 \\
\hline Claims on nonbank financial institutions & 6 & 37 & 36 & 36 & 49 & 44 & 29 & 56 \\
\hline Other items (net) & $-8,889$ & $-8,075$ & $-8,102$ & $-8,110$ & $-7,851$ & $-8,825$ & $-9,080$ & $-7,567$ \\
\hline Broad money (M2) & 52,358 & 56,884 & 57,970 & 59,710 & 58,915 & 61,183 & 61,549 & 66,817 \\
\hline Narrow money (M1) & 22,621 & 22,989 & 22,104 & 22,301 & 22,731 & 23,153 & 25,138 & 27,223 \\
\hline Currency outside banks & 6,459 & 6,516 & 5,925 & 5,971 & 5,935 & 5,986 & 6,637 & 7,005 \\
\hline Demand deposits & 16,162 & 16,474 & 16,180 & 16,330 & 16,796 & 17,168 & 18,501 & 20,218 \\
\hline Quasi money & 27,636 & 31,662 & 33,378 & 34,639 & 33,742 & 35,137 & 33,501 & 36,081 \\
\hline Time deposits & 25,857 & 29,983 & 30,842 & $\ldots$ & 32,106 & 33,768 & 32,124 & 34,586 \\
\hline Other quasi-monetary deposits & 1,779 & 1,679 & 2,536 & $\ldots$ & 1,636 & 1,369 & 1,377 & 1,495 \\
\hline \multirow[t]{2}{*}{ Foreign currency deposits } & 2,101 & 2,232 & 2,488 & 2,770 & 2,442 & 2,892 & 2,909 & 3,513 \\
\hline & \multicolumn{8}{|c|}{ (Change in percent of broad money 12 months earlier) } \\
\hline Net foreign assets & 3.9 & -1.7 & -0.7 & 1.8 & 1.6 & 5.5 & 2.7 & 2.9 \\
\hline Net domestic assets & 10.5 & 10.3 & 8.4 & 7.2 & 5.9 & 5.8 & 5.5 & 5.7 \\
\hline Net domestic credit & 12.7 & 8.8 & 8.7 & 7.7 & 6.0 & 6.9 & 7.3 & 3.2 \\
\hline Net claims on the central government & 5.9 & 0.9 & 1.2 & 1.9 & -0.4 & 0.5 & 0.7 & 0.2 \\
\hline Credit to the economy & 5.9 & 7.3 & 6.6 & 5.1 & 6.0 & 5.8 & 5.3 & 3.7 \\
\hline Credit to public enterprises & 0.0 & -0.1 & -0.1 & -0.1 & 0.0 & -0.1 & 0.0 & 0.0 \\
\hline Credit to private sector & 5.9 & 7.3 & 6.6 & 5.1 & 5.9 & 5.8 & 5.3 & 3.6 \\
\hline Valuation & 0.0 & 0.0 & 0.0 & 0.0 & 0.0 & 0.0 & 0.0 & 0.0 \\
\hline Other items (net) & -2.3 & 1.6 & -0.3 & -0.5 & -0.1 & -1.1 & -1.8 & 2.5 \\
\hline Broad money & 14.3 & 8.6 & 7.7 & 9.0 & 7.6 & 11.2 & 8.2 & 8.6 \\
\hline \multicolumn{9}{|l|}{ Selected monetary indicators } \\
\hline Income velocity of money & 1.54 & 1.51 & $\ldots$ & $\ldots$ & $\ldots$ & $\ldots$ & 1.46 & 1.48 \\
\hline Emigrant deposits & 19,042 & 22,153 & 22,676 & 23,276 & 23,406 & 24,470 & 24,476 & 27,392 \\
\hline Excess reserves /total deposits (in percent) & 0.5 & 0.1 & 0.3 & 0.4 & 0.8 & 2.0 & 2.0 & 0.1 \\
\hline Money multilplier (M2 / M0) & 3.22 & 3.29 & 3.38 & 3.25 & 3.38 & 3.25 & 3.34 & 3.39 \\
\hline Credit to the economy (percentage change) & 12.0 & 15.2 & 13.8 & 10.3 & 12.1 & 11.5 & 10.4 & 7.1 \\
\hline
\end{tabular}


Table 3. Cape Verde: Monetary Survey, 2002-05 (continued)

\begin{tabular}{|c|c|c|c|c|c|c|c|c|}
\hline & \multirow{3}{*}{$\frac{2002}{\text { Dec. }}$} & \multirow{3}{*}{$\begin{array}{l}2003 \\
\text { Dec. } \\
\text { Prel. }\end{array}$} & \multicolumn{5}{|c|}{2004} & \multirow{3}{*}{$\begin{array}{r}2005 \\
\text { Dec. } \\
\text { ev. Proj }\end{array}$} \\
\hline & & & \multirow[t]{2}{*}{ March } & \multicolumn{2}{|c|}{ June } & \multirow{2}{*}{$\begin{array}{l}\text { Sep. } \\
\text { Proj. }\end{array}$} & \multirow{2}{*}{$\begin{array}{c}\text { Dec. } \\
\text { Prog. }\end{array}$} & \\
\hline & & & & Prog. & Prel. & & & \\
\hline \multicolumn{9}{|c|}{ (In millions of Cape Verde escudos, unless otherwise specified) } \\
\hline \multicolumn{9}{|l|}{ Bank of Cape Verde } \\
\hline Net foreign assets & 8,632 & 8,088 & 8,390 & 9,185 & 9,237 & 10,431 & 9,230 & 10,902 \\
\hline Of which: net international reserves & 7,984 & 7,528 & 7,820 & 8,465 & 8,667 & 9,865 & 8,824 & 10,496 \\
\hline Foreign assets & 9,135 & 8,818 & 9,135 & 9,929 & 9,977 & 11,324 & 10,132 & 12,135 \\
\hline Foreign liabilities & -503 & -730 & -745 & -744 & -740 & -893 & -902 & $-1,233$ \\
\hline Net domestic assets & 7,605 & 9,201 & 8,764 & 9,201 & 8,205 & 8,413 & 9,172 & 8,814 \\
\hline Net domestic credit & 9,728 & 10,651 & 10,197 & 10,641 & 9,638 & 10,098 & 10,658 & 9,711 \\
\hline Trust Fund claims & 4,167 & 4,605 & 4,605 & 4,605 & 4,605 & 4,605 & 4,755 & 4,655 \\
\hline Net claims on central government & 4,103 & 4,424 & 4,232 & 4,676 & 3,786 & 4,251 & 4,451 & 3,607 \\
\hline Credit to central government & 5,302 & 5,373 & 5,157 & 5,594 & 5,307 & 5,189 & 5,339 & 4,395 \\
\hline Deposits of central government & $-1,199$ & -948 & -925 & -918 & $-1,522$ & -938 & -888 & -788 \\
\hline Of which: project accounts & -397 & -393 & -351 & -351 & -983 & -287 & -287 & -237 \\
\hline Of which: foreign currency deposits & -330 & -456 & -469 & -469 & -450 & -563 & -563 & -513 \\
\hline Claims on local government & 0 & 0 & 0 & 0 & 0 & 0 & 0 & 0 \\
\hline Credit to the economy & 1,184 & 1,212 & 1,208 & 1,208 & 1,195 & 1,198 & 1,308 & 1,380 \\
\hline Credit to public enterprises & 72 & 72 & 72 & 72 & 67 & 61 & 71 & 71 \\
\hline Credit to private sector & 1,112 & 1,107 & 1,103 & 1,103 & 1,096 & 1,106 & 1,206 & 1,258 \\
\hline Claims on nonbank financial institutions & 0 & 33 & 33 & 33 & 33 & 31 & 31 & 51 \\
\hline Credit to commercial banks & 275 & 410 & 152 & 152 & 52 & 44 & 144 & 69 \\
\hline Valuation & 0 & 0 & 0 & 0 & 0 & 0 & 0 & 0 \\
\hline Other items (net) & $-2,123$ & $-1,451$ & $-1,433$ & $-1,440$ & $-1,433$ & $-1,685$ & $-1,485$ & -897 \\
\hline Assets & 2,345 & 2,396 & 2,418 & $\ldots$ & 2,437 & 2,468 & 2,468 & 2,841 \\
\hline Liabilities & 4,468 & 3,847 & 3,852 & $\ldots$ & 3,870 & 4,153 & 4,153 & 3,738 \\
\hline Reserve money (M0) & 16,237 & 17,289 & 17,153 & 18,386 & 17,442 & 18,844 & 18,402 & 19,715 \\
\hline Currency outside banks & 6,459 & 6,516 & 5,925 & 5,971 & 5,935 & 5,986 & 6,637 & 7,005 \\
\hline Cash in vaults & 1,013 & 808 & 828 & 1,591 & 661 & 894 & 894 & 903 \\
\hline Deposits of commercial banks & 8,764 & 9,964 & 10,399 & 10,823 & 10,846 & 11,962 & 10,871 & 11,807 \\
\hline Deposits of private sector & 0.0 & 0.0 & 0.0 & 0.0 & 0.0 & 0.0 & 0 & 0 \\
\hline Deposits of other financial institutions & 1 & 0 & 1 & 1 & 1 & 1 & 0 & 0 \\
\hline Gross international reserves (mn. Euros) & 76.1 & 74.1 & 76.9 & 84.1 & 84.5 & 96.8 & 87.4 & 105.6 \\
\hline Net international reserves (mn. Euros) & 72.4 & 68.2 & 70.9 & 76.7 & 78.6 & 89.5 & 80.0 & 95.2 \\
\hline Reserve money (12-month change in percent) & 11.4 & 6.5 & 1.6 & 7.9 & 2.4 & 10.6 & 6.4 & 7.1 \\
\hline
\end{tabular}


Table 3. Cape Verde: Monetary Survey, 2002-05 (concluded)

\begin{tabular}{|c|c|c|c|c|c|c|c|c|}
\hline & \multirow{3}{*}{$\begin{array}{l}2002 \\
\text { Dec. }\end{array}$} & \multirow{3}{*}{$\begin{array}{l}2003 \\
\text { Dec. }\end{array}$} & \multicolumn{5}{|c|}{2004} & \multirow{3}{*}{$\begin{array}{l}2005 \\
\text { Dec. } \\
\text { Proj. }\end{array}$} \\
\hline & & & \multirow[t]{2}{*}{ March } & \multicolumn{2}{|c|}{ June } & \multirow{2}{*}{$\begin{array}{l}\text { Sep. } \\
\text { Prel. }\end{array}$} & \multirow{2}{*}{$\frac{\text { Dec. }}{\text { Rev. Proj. }}$} & \\
\hline & & & & Prog. & Prel. & & & \\
\hline \multicolumn{9}{|l|}{ Commercial banks } \\
\hline Net foreign assets & 2,699 & 2,368 & 2,780 & 2,521 & 2,356 & 3,084 & 2,784 & 2,846 \\
\hline Foreign assets & 4,706 & 4,616 & 5,004 & 5,004 & 4,581 & 5,501 & 5,301 & 5,663 \\
\hline Foreign liabilities & $-2,007$ & $-2,248$ & $-2,224$ & $-2,483$ & $-2,226$ & $-2,417$ & $-2,517$ & $-2,817$ \\
\hline of which: Nonresident deposits & $-1,650$ & $-1,847$ & $-1,886$ & $-2,069$ & $-1,847$ & $-2,028$ & $-2,028$ & $-2,028$ \\
\hline Net domestic assets & 43,199 & 48,000 & 49,265 & 51,217 & 50,623 & 52,112 & 52,127 & 56,966 \\
\hline Net domestic credit & 49,964 & 54,625 & 55,933 & 57,887 & 57,042 & 59,251 & 58,541 & 63,636 \\
\hline Net claims on general government & 16,521 & 16,531 & 16,672 & 17,054 & 16,497 & 16,477 & 17,185 & 18,139 \\
\hline Trust Fund claims & 6,433 & 6,433 & 6,433 & 6,433 & 6,433 & 6,433 & 6,433 & 6,433 \\
\hline Other government deposits (INPS) & -186 & -402 & -442 & -442 & -646 & -524 & -124 & -114 \\
\hline Net claims on central government & 10,265 & 10,433 & 10,601 & 10,982 & 10,619 & 10,449 & 10,807 & 11,750 \\
\hline Loans and overdrafts & 6,704 & 7,302 & 7,381 & 7,381 & 7,102 & 7,035 & 6,735 & 6,635 \\
\hline Holding of government securities & 4,540 & 4,423 & 4,575 & 4,957 & 4,691 & 4,754 & 5,312 & 6,368 \\
\hline Deposits of central government & -979 & $-1,291$ & $-1,355$ & $-1,355$ & $-1,175$ & $-1,340$ & $-1,240$ & $-1,252$ \\
\hline Net claims on local government & 8 & 67 & 80 & 80 & 91 & 120 & 70 & 70 \\
\hline Claims on local government & 266 & 239 & 231 & 231 & 236 & 219 & 269 & 269 \\
\hline Deposits of local government & -259 & -172 & -151 & -151 & -144 & -99 & -199 & -199 \\
\hline Credit to the economy & 23,941 & 27,731 & 28,186 & 28,570 & 29,091 & 29,962 & 29,735 & 32,856 \\
\hline Credit to public enterprises & 158 & 108 & 95 & 95 & 116 & 100 & 125 & 137 \\
\hline Credit to private sector & 23,778 & 27,619 & 28,088 & 28,472 & 28,958 & 29,849 & 29,605 & 32,713 \\
\hline Claims on nonbank financial institutions & 6 & 4 & 3 & 3 & 17 & 13 & 5 & 5 \\
\hline Net claims on the Bank of Cape Verde & 9,502 & 10,363 & 11,075 & 12,263 & 11,454 & 12,812 & 11,621 & 12,641 \\
\hline Total reserves & 9,777 & 10,772 & 11,227 & 12,415 & 11,506 & 12,856 & 11,765 & 12,710 \\
\hline Vault cash & 1,013 & 808 & 828 & 1,591 & 661 & 894 & 894 & 903 \\
\hline Deposits with central bank & 8,764 & 9,964 & 10,399 & 10,823 & 10,846 & 11,962 & 10,871 & 11,807 \\
\hline Required reserves & 8,518 & 9,924 & 10,259 & 10,603 & 10,439 & 10,860 & 10,818 & 11,750 \\
\hline Excess reserves & 246 & 40 & 140 & 220 & 406 & 1,102 & 52 & 58 \\
\hline Credit from the Bank of Cape Verde & -275 & -410 & -152 & -152 & -52 & -44 & -144 & -69 \\
\hline Other items (net) & $-6,765$ & $-6,625$ & $-6,668$ & $-6,669$ & $-6,418$ & $-7,140$ & $-6,414$ & $-6,670$ \\
\hline Deposit liabilities to nonbank residents & 45,898 & 50,368 & 52,045 & 53,739 & 52,979 & 55,196 & 54,911 & 59,812 \\
\hline Local currency deposits & 43,796 & 48,135 & 49,556 & 50,969 & 50,537 & 52,304 & 52,002 & 56,299 \\
\hline Demand deposits & 16,161 & 16,473 & 16,178 & 16,330 & 16,795 & 17,166 & 18,501 & 20,218 \\
\hline Of which: emigrant deposits & 2,133 & 2,202 & 2,174 & $\ldots$ & 2,371 & 2,426 & 2,426 & 2,989 \\
\hline Quasi money & 27,636 & 31,662 & 33,378 & 37,409 & 33,742 & 35,137 & 33,501 & 36,081 \\
\hline Time deposits & 25,857 & 29,983 & 30,842 & $\ldots$ & 32,106 & 33,768 & 32,124 & 34,586 \\
\hline Of which : emigrant deposits & 15,817 & 18,918 & 19,472 & $\ldots$ & 20,038 & 21,048 & 21,048 & 23,561 \\
\hline Other quasi-monetary deposits & 1,779 & 1,679 & 2,536 & $\ldots$ & 1,636 & 1,369 & 1,377 & 1,495 \\
\hline Foreign currency deposits & 2,101 & 2,232 & 2,488 & 2,770 & 2,442 & 2,892 & 2,909 & 3,513 \\
\hline Of which: emigrant deposits & 1,092 & 1,033 & 1,030 & 1,030 & 998 & 997 & 1,002 & 842 \\
\hline \multicolumn{9}{|l|}{ Memorandum items: } \\
\hline Emigrant deposits (as ratio to total deposits) & 0.36 & 0.39 & 0.39 & $\ldots$ & $\ldots$ & $\ldots$ & 0.40 & 0.41 \\
\hline Other deposits (as ratio to total deposits) & 0.64 & 0.61 & 0.61 & $\ldots$ & $\ldots$ & $\ldots$ & 0.60 & 0.59 \\
\hline Composition of emigrant deposits & 1.00 & 1.00 & 1.00 & $\ldots$ & $\ldots$ & $\ldots$ & 1.00 & 1.00 \\
\hline Local currency & 0.94 & 0.95 & 0.95 & $\ldots$ & $\ldots$ & $\ldots$ & 0.96 & 0.97 \\
\hline Demand & 0.11 & 0.10 & 0.10 & $\ldots$ & $\ldots$ & $\ldots$ & 0.10 & 0.11 \\
\hline Time & 0.83 & 0.85 & 0.86 & $\ldots$ & $\ldots$ & $\ldots$ & 0.86 & 0.86 \\
\hline Foreign currency & 0.06 & 0.05 & 0.05 & $\ldots$ & $\ldots$ & $\ldots$ & 0.04 & 0.03 \\
\hline
\end{tabular}

Sources: Bank of Cape Verde; and staff estimates and projections.

CInternational Monetary Fund. Not for Redistribution 
Table 4. Cape Verde: Balance of Payments, 2001-05

(In millions of Cape Verde escudos, unless otherwise indicated)

\begin{tabular}{|c|c|c|c|c|c|c|c|}
\hline & \multirow[t]{2}{*}{2001} & \multirow[t]{2}{*}{2002} & \multicolumn{2}{|c|}{2003} & \multicolumn{2}{|c|}{2004} & \multirow{2}{*}{$\begin{array}{l}2005 \\
\text { Proj. }\end{array}$} \\
\hline & & & Program 1/ & Actual & Program 1/ & Proj. & \\
\hline Current account balance & $-7,016$ & $-8,314$ & $-8,392$ & $-7,539$ & $-9,183$ & $-6,746$ & $-7,819$ \\
\hline Trade balance & $-23,958$ & $-27,673$ & $-29,872$ & $-28,253$ & $-31,380$ & $-29,412$ & $-32,476$ \\
\hline Exports, f.o.b. & 4,577 & 4,909 & 4,883 & 5,150 & 5,462 & 5,044 & 5,381 \\
\hline Imports, f.o.b. & $-28,535$ & $-32,583$ & $-34,755$ & $-33,403$ & $-36,842$ & $-34,456$ & $-37,857$ \\
\hline Services (net) & 1,312 & 1,242 & 1,186 & 1,342 & 1,629 & 2,311 & 2,986 \\
\hline Credit & 15,981 & 17,808 & 18,761 & 19,578 & 20,317 & 21,193 & 23,349 \\
\hline Of which: tourism & 6,539 & 7,509 & 7,767 & 8,152 & 8,505 & 9,242 & 10,256 \\
\hline Debit & $-14,668$ & $-16,565$ & $-17,575$ & $-18,236$ & $-18,689$ & $-18,883$ & $-20,363$ \\
\hline Factor income (net) & -753 & $-1,364$ & $-1,569$ & $-1,134$ & $-1,484$ & -943 & -827 \\
\hline Credit & 830 & 787 & 697 & 1,516 & 775 & 1,455 & 1,737 \\
\hline Debit & $-1,583$ & $-2,151$ & $-2,266$ & $-2,650$ & $-2,259$ & $-2,398$ & $-2,564$ \\
\hline Government interest & -568 & -557 & -578 & -514 & -572 & -556 & -552 \\
\hline Interest by other sectors & -859 & -896 & -934 & $-1,874$ & $-1,104$ & $-1,366$ & $-1,426$ \\
\hline Income on direct investment and other income & -156 & -699 & -754 & -261 & -583 & -475 & -585 \\
\hline Current transfers (net) & 16,382 & 19,482 & 21,864 & 20,507 & 22,052 & 21,297 & 22,498 \\
\hline Government & 2,601 & 4,159 & 5,651 & 4,401 & 4,882 & 4,874 & 3,866 \\
\hline Other & 13,781 & 15,323 & 16,212 & 16,106 & 17,169 & 16,423 & 18,632 \\
\hline Capital and financial account (net) & 9,545 & 11,329 & 9,071 & 6,278 & 7,413 & 7,833 & 9,491 \\
\hline Capital transfers & 3,004 & 1,058 & 975 & 2,071 & 1,121 & 2,050 & 1,850 \\
\hline Government & 0 & 244 & 975 & 441 & 1,121 & 0 & 0 \\
\hline Other & 3,004 & 814 & 0 & 1,630 & 0 & 2,050 & 1,850 \\
\hline Direct investment (net) & 983 & 1,718 & 1,890 & 1,350 & 2,174 & 1,510 & 1,532 \\
\hline Portfolio investment & 180 & 0 & 0 & 0 & 0 & 0 & 0 \\
\hline Government & 2,113 & 1,150 & 3,148 & 3,004 & 1,758 & 2,806 & 2,412 \\
\hline Trust Fund & 0 & 0 & 0 & 1,006 & 0 & 0 & 0 \\
\hline Net official flows & 2,113 & 1,150 & 3,148 & 1,998 & 1,758 & 2,806 & 2,412 \\
\hline Disbursements & 7,557 & 4,144 & 5,278 & 4,099 & 4,381 & 5,180 & 4,490 \\
\hline Amortization & $-5,444$ & $-2,995$ & $-2,131$ & $-2,101$ & $-2,623$ & $-2,374$ & $-2,077$ \\
\hline Other capital & 3,265 & 7,404 & 3,058 & -147 & 2,360 & 1,467 & 3,697 \\
\hline Commercial banks & -115 & 1,082 & 521 & 3,261 & -8 & -416 & 782 \\
\hline Emigrant deposit flows & 3,108 & 3,457 & 2,382 & 3,111 & 2,368 & 2,323 & 2,916 \\
\hline Commercial credit (net) & 663 & 2,577 & 155 & -171 & 0 & 0 & 0 \\
\hline Other & -391 & 288 & 0 & $-6,348$ & 0 & -440 & 0 \\
\hline Net errors and omissions & -636 & -328 & 0 & 760 & 0 & 0 & 0 \\
\hline Overall balance & 1,892 & 2,687 & 678 & -500 & $-1,770$ & 1,087 & 1,672 \\
\hline Financing & $-1,892$ & $-2,687$ & -678 & 500 & $-1,102$ & $-1,087$ & $-1,672$ \\
\hline Flow in NFA of central bank ( $-=$ accumulation $)$ & $-1,892$ & $-2,687$ & -678 & 68 & $-1,102$ & $-1,142$ & $-1,672$ \\
\hline Change in stocks $(-=$ increase $)$ & & & & 544 & & & \\
\hline Valuation change ( $-=$ increase in stocks due valuation) & & & & 476 & & & \\
\hline Of which: change in net international reserves & $-1,879$ & $-2,884$ & -752 & 456 & $-1,102$ & $-1,296$ & $-1,672$ \\
\hline Of which: IMF (net) 3/ & 0 & 354 & 417 & 291 & 358 & 172 & 331 \\
\hline Exceptional financing & 0 & 0 & 0 & 432 & 0 & 55 & 0 \\
\hline Change in government arrears (+=increase) & $-1,855$ & 0 & -802 & 0 & 0 & 0 & 0 \\
\hline Rescheduling/cancellation of arrears & 1,855 & 0 & 802 & 0 & 0 & 0 & 0 \\
\hline Financing gap & 0 & 0 & 0 & 0 & 2,872 & 0 & 0 \\
\hline \multicolumn{8}{|l|}{ Memorandum items: } \\
\hline Current account (including official transfers) 2/ & -9.9 & -11.0 & -10.3 & -9.2 & -10.5 & -7.8 & -8.2 \\
\hline Current account (excluding official transfers) $2 /$ & -13.6 & -16.5 & -17.3 & -14.5 & -16.1 & -13.4 & -12.3 \\
\hline Overall balance 2/ & 2.7 & 3.6 & 0.8 & -0.6 & -2.0 & 1.3 & 1.8 \\
\hline Gross international reserves & 5,238 & 8,391 & 9,507 & 8,173 & 10,967 & 9,641 & 11,644 \\
\hline In months of imports of goods and nonfactor services & 1.5 & 2.0 & 2.2 & 1.9 & 2.4 & 2.2 & 2.4 \\
\hline External public debt & 44,052 & 41,064 & 43,419 & 36,951 & 45,177 & 39,364 & 40,537 \\
\hline
\end{tabular}

1/ As contained in the August 6, 2004 staff report (IMF Country Report 04/304).

2/ In percent of GDP.

3/ The IMF disbursement for 2005 represents the two final disbursements under the current PRGF arrangement. 
Table 5. Cape Verde: External Public Debt Outstanding, 2001-04

(In millions of U.S. dollars, unless otherwise indicated; end of period)

\begin{tabular}{|c|c|c|c|c|}
\hline & 2001 & 2002 & 2003 & $\begin{array}{l}2004 \\
\text { Proj. }\end{array}$ \\
\hline Multilateral & 252.2 & 288.4 & 315.9 & 308.4 \\
\hline AfDF 1/ & 86.2 & 85.5 & 95.5 & 94.0 \\
\hline IDA & 110.1 & 143.4 & 158.1 & 157.2 \\
\hline IMF & 0.0 & 3.3 & 6.9 & 6.9 \\
\hline BADEA $1 /$ & 20.6 & 20.6 & 22.5 & 20.2 \\
\hline AfDB 1/ & 1.3 & 0.6 & 0.2 & 0.0 \\
\hline EIB 1/ & 8.1 & 7.0 & 8.7 & 7.4 \\
\hline OPEC $1 /$ & 7.7 & 10.7 & 11.2 & 10.2 \\
\hline IFAD 1/ & 8.9 & 9.1 & 9.9 & 9.6 \\
\hline Saudi Fund 1/ & 0.3 & 0.0 & 0.0 & 0.0 \\
\hline NDF $1 /$ & 2.9 & 2.7 & 2.9 & 2.9 \\
\hline NTF 1/ & 6.2 & 5.4 & 0.0 & 0.0 \\
\hline Bilateral & 77.2 & 82.2 & 91.7 & 77.0 \\
\hline Government & 56.0 & 67.7 & 70.3 & 63.0 \\
\hline China & 0.0 & 0.0 & 0.0 & 0 \\
\hline Kuwait & 4.4 & 2.9 & 3.7 & 3.4 \\
\hline Portugal & 41.3 & 44.1 & 46.7 & 42.3 \\
\hline South Africa & 0.0 & 0.0 & 0.0 & 0.0 \\
\hline Abu Dhabi & 0.2 & 0.1 & 0.0 & 0.0 \\
\hline Germany & 10.1 & 20.6 & 19.9 & 17.4 \\
\hline Export credit agencies & 21.2 & 14.5 & 21.5 & 14.0 \\
\hline Caisse Général des Dépôts & 4.7 & 7.0 & 8.3 & 6.9 \\
\hline ICO (Spain) & 7.9 & 1.2 & 6.6 & 4.4 \\
\hline CACEX (Brazil) & 2.4 & 2.4 & 2.6 & 0.0 \\
\hline SOMEC (Portugal) & 6.3 & 3.9 & 4.0 & 2.6 \\
\hline Private companies & 8.2 & 12.4 & 15.6 & 12.8 \\
\hline Banco Espirito Santo & 7.5 & 11.8 & 15.6 & 12.8 \\
\hline MSF (Portugal) & 0.7 & 0.7 & 0.0 & 0.0 \\
\hline Total (excluding arrears) 2/ & 337.6 & 383.0 & 423.2 & 454.2 \\
\hline As percent of GDP & 59.8 & 53.4 & 44.9 & 47.6 \\
\hline Stock of external debt arrears & 14.5 & 7.5 & 0.0 & 0.0 \\
\hline Total (including arrears) & 352.1 & 390.5 & 423.2 & 454.2 \\
\hline As percent of GDP & 62.4 & 54.4 & 44.9 & 47.6 \\
\hline Total (including arrears and financing gap) & 352.1 & 390.5 & 423.2 & 454.2 \\
\hline As percent of GDP & 62.4 & 54.4 & 44.9 & 47.6 \\
\hline In millions of Cape Verde escudos & 44,052 & 41,064 & 36,951 & 41,116 \\
\hline
\end{tabular}

Source: Cape Verdean authorities.

1/ AfDF = African Development Fund; BADEA = Arab Bank for Economic Development for Africa; AfDB = African Development Bank; EIB = European Investment Bank; OPEC = Organization of Petroleum Exporting Countries; IFAD = International Fund for Agricultural Development; Saudi Fund = Saudi Fund for Development; NDF = Nordic Development Fund; and NTF $=$ Nigeria Trust Fund. 


\begin{tabular}{|c|c|c|c|c|c|c|c|}
\hline & 1998 & 1999 & 2000 & 2001 & 2002 & 2003 & $\begin{array}{l}2004 \\
\text { Proj. }\end{array}$ \\
\hline & \multicolumn{5}{|c|}{ (In units as indicated) } & & \\
\hline Real effective exchange rate (annual percentage change) 1/ & -0.5 & 5.3 & -7.4 & 0.2 & 2.6 & 3.4 & -2.1 \\
\hline Nominal effective exchange rate (annual percentage change) $1 /$ & -2.2 & 3.7 & -1.9 & 0.2 & 4.0 & 6.3 & 1.7 \\
\hline Nominal Cape Verde escudos-U.S. dollar rate (annual percentage change) 2/ & 5.3 & 5.4 & 15.6 & 3.0 & -4.9 & -16.6 & -8.1 \\
\hline Domestic credit growth (annual percentage change) & 5.6 & 11.3 & 25.2 & 7.1 & 13.2 & 9.2 & 6.8 \\
\hline Overall fiscal balance, including grants (in percent of GDP) & -3.9 & -12.5 & -19.5 & -4.6 & -2.5 & -3.2 & -2.9 \\
\hline Public debt (in percent of GDP) & 81.8 & 86.1 & 107.5 & 106.2 & 98.5 & 86.6 & 86.8 \\
\hline Domestic debt, including claims on the offshore Trust Fund (in percent of GDP) & 36.9 & 32.9 & 48.0 & 43.8 & 44.1 & 41.7 & 39.2 \\
\hline Domestic debt, excluding claims on the offshore Trust Fund (in percent of GDP) & 36.9 & 21.9 & 31.6 & 28.8 & 30.0 & 28.8 & 27.0 \\
\hline External debt (in percent of GDP) & 44.9 & 53.2 & 59.5 & 62.4 & 54.4 & 44.9 & 47.6 \\
\hline Scheduled external debt service relative to gross international reserves (in percent) & 167.7 & 87.8 & 56.2 & 114.8 & 42.3 & 32.0 & 30.4 \\
\hline Scheduled external debt service relative to fiscal domestic revenues (in percent) & 13.0 & 32.1 & 14.2 & 40.5 & 21.3 & 14.9 & 14.3 \\
\hline Gross international reserves (in months of imports of goods and nonfactor services) & 0.3 & 1.5 & 1.0 & 1.5 & 2.0 & 1.9 & 2.2 \\
\hline Broad money relative to official reserves (in percent) & $4,081.0$ & 789.7 & $1,245.3$ & 874.3 & 624.0 & 696.0 & 638.4 \\
\hline Broad money relative to net foreign assets (in percent) & 572.0 & 455.5 & 584.1 & 479.2 & 462.1 & 544.0 & 513.2 \\
\hline Central bank lending rate & 10.0 & 8.5 & 9.5 & 11.5 & 10.0 & 8.5 & 8.5 \\
\hline Private transfers (in percent of GDP) & 15.7 & 18.4 & 21.0 & 19.5 & 20.3 & 19.6 & 19.0 \\
\hline Current account, excluding official current transfers (in percent of GDP) & -21.4 & -20.6 & -15.3 & -13.6 & -16.5 & -14.5 & -13.4 \\
\hline Exports of goods and nonfactor services relative to imports of goods and nonfactor services (in percent) & 38.6 & 37.0 & 44.3 & 47.6 & 46.2 & 47.9 & 49.2 \\
\hline Tourism receipts and foreign direct investment (in percent of GDP) & 5.5 & 13.5 & 13.5 & 10.7 & 12.2 & 11.5 & 12.4 \\
\hline Tourism receipts (annual percentage change) & 41.7 & 46.3 & 66.2 & 35.6 & 14.8 & 8.6 & 13.4 \\
\hline
\end{tabular}

Sources: Cape Verdean authorities; and staff estimates and projections.

1/ A minus sign symbolizes a depreciation.

2/ A minus sign symbolizes an appreciation. 
Table 7. Cape Verde: Proposed Schedule of Disbursement Under the PRGF Arrangement, 2002-05

Amount Available Date $\quad$ Conditions Necessary for Disbursement 1/

SDR 1.23 million

SDR 1.23 million

SDR 1.23 million

SDR 1.23 million

SDR 1.23 million

SDR 1.23 million

SDR 1.26 million
April 4, 2002

December 16, 2002

June 25, 2003

December 19, 2003

August 27, 2004

January 31, 2005

May 31, 2005
Executive Board approval of the three-year annual arrangement.

Observance of the perfornance criteria for June 30, 2002 and completion of the first review under the arrangement.

Observance of the performance criteria for December 31, 2002 and completion of the second review under the arrangement.

Observance of the performance criteria for June 30, 2002 and completion of the third review under the arrangement.

Observance of the performance criteria for December 31, 2003 and completion of the fourth review under the arrangement.

Observance of the performance criteria for June 30, 2004 and completion of the fifth review under the arrangement.

Observance of the performance criteria for December 31, 2004 and completion of the sixth review under the arrangement.

Source: International Monetary Fund.

1/ Other than the generally applicable conditions under the Poverty Reduction and Growth Facility (PRGF) arrangement. 
Table 8. Cape Verde: Millennium Development Goals

Goal 1. Eradicate extreme poverty and hunger

Target 1: Halve between 1990 and 2015, the proportion of people whose income

is less than one dollar a day.

1. Population below US\$ 1 a day (percent)

2. Poverty gap ratio at US\$ 1 a day (percent)

3 . Share of income or consumption held by poorest 20 percent (percent)

3a. Percentage of poor, 2001-2002

3 b. Incidence of absolute poverty $1 /$

$\begin{array}{rrrrr}\ldots & \ldots & \ldots & \ldots & \ldots \\ \ldots & \ldots & \ldots & \ldots & \ldots \\ \ldots & \ldots & \ldots & \ldots & \ldots \\ \ldots & \ldots & 30.0 & \ldots & \ldots \\ 49.02 / & \ldots & \ldots & 37.0 & 25.0\end{array}$

Target 2: Halve, between 1990 and 2015, the proportion of people suffering hunger

4. Prevalence of child malnutrition (percent of children under 5)

5. Population below minimum level of dietary energy consumption (percent)

Goal 2. Achieve universal primary education

Target 3: Ensure that, by 2015, children will be able to complete a full course of primary schooling

6. Net primary enrollment ratio (percent of relevant age group)

7. Percentage of cohort reaching grade 5

8. Youth literacy rate (percent age 15-24)

Goal 3. Promote gender equality and empower women

Target 4: Eliminate gender disparity in primary and secondary education preferably by 2005 and to all levels of education by 2015

9. Ratio of girls to boys in primary and secondary education (percent)

10. Ratio of young literate females to males (percent ages 15-24)

11. Share of women employed in the nonagricultural sector (percent)

12. Proportion of seats held by women in the national parliament (percent)

$\begin{array}{rrrrr}\ldots & 96.1 & \ldots & \ldots & 100.0 \\ 87.5 & 90.4 & 93.3 & 93.8 & 100.0 \\ \ldots & \ldots & \ldots & \ldots & \ldots \\ 12.0 & 11.0 & 11.0 & 11.0 & \ldots\end{array}$

\section{Goal 4. Reduce child mortality}

Target 5: reduce by two-thirds between 1990 and 2015, the under-five mortality rate

13. Under-five mortality rate (per 1,000$)$

14. Infant mortality rate (per 1,000 live births)

15. Immunization against measles (percent of children under 12-months)

\section{Goal 5. Improve maternal health}

Target 6: Reduce by three-quarters, between 1990 and 2015, the maternal mortality ratio.

16. Maternal mortality ratio (modeled estimate, per 100,000 live births)

17. Proportion of births attended by skilled health personnel

Goal 6. Combat HIV/AIDS, malaria and other diseases

Target 7: Halt by 2015, and begin to reverse, the spread of HIV/AIDS

18. HIV prevalence among females (percent ages 15-24)

19. Contraceptive prevalence rate (percent of women ages 15-49)

20. Number of children orphaned by HIV/AIDS

Target 8: Halt by 2015, and begin to reverse, the incidence of malaria and other major diseases 
Table 8. Cape Verde: Millennium Development Goals (concluded)

Goal 7. Ensure environmental sustainability

Target 9: Integrate the principles of sustainable development into policies and programs. Reverse the loss of environmental resources

25. Forest area (percent of total land area)

26. Nationally protected areas (percent of total land area)

27. GDP per unit of energy use (PPP \$ per kg oil equivalent)

28. $\mathrm{CO} 2$ emissions (metric tons per capita)

Target 10: Halve by 2015 proportion of people without access to safe drinking water

30. Access to improved water source (percent of population)

Target 11: Achieve by 2020 significant improvement for at least 100 million slum dwellers

31. Access to improved sanitation (percent of population)

32. Access to secure tenure (percent of population)

Goal 8. Develop a Global Partnership for Development 3/
$8.7 \quad \ldots \quad 21.1$

... $0.0 \quad 0.0$

.

$0.3=0.3-\cdots+\cdots$

$\begin{array}{llll}\cdots & & & \end{array}$

Target 16: Develop and implement strategies for productive work for youth.

45. Unemployment rate of population ages 15-24 (total)

Target 18: Make available new technologies, especially information and communications

47. Fixed line and mobile telephones (per 1,000 people)

48. Personal computers (per 1,000 people) $\quad \ldots \quad 21.5$

$\begin{array}{lll}. . & 81.7 \quad 68.6\end{array}$

Sources: World Bank; and Fund staff estimates.

1/ Absolute poverty measures the number of people in 1988 and 2002 whose income is below the 1988 national poverty line, indexed for inflation. 2/ Data for 1988.

3/ Targets 12-15 and indicators 29, 33-44 are excluded because they can not be measured on a country specific basis. These are related to official development, 


\section{Cape Verde: Relations with the Fund}

(As of November 30, 2004)

I. Membership Status: Joined on 11/20/1978; Article XIV

II. General Resources Account:

Quota

Fund holdings of currency

Reserve position in Fund

III. SDR Department:

Net cumulative allocation

Holdings

IV. Outstanding Purchases and Loans:

Poverty Reduction and Growth

Facility (PRGF) Arrangement $\underline{\text { SDR million }}$

9.60

9.60

0.00

$\underline{\text { SDR million }}$

0.62

0.02

$\underline{\text { SDR million }}$

6.15
\%Quota 100.0

99.96

0.05

\%Allocation

100.0

3.65

$\%$ Quota

64.06

V. Financial Arrangements:

$\begin{array}{lcccc}\text { Type } & \begin{array}{c}\text { Approval } \\ \text { date }\end{array} & \begin{array}{c}\text { Expiration } \\ \text { date }\end{array} & \begin{array}{c}\text { Amount approved } \\ \text { (SDR million) }\end{array} & \begin{array}{c}\text { Amount drawn } \\ \text { (SDR million) }\end{array} \\ \text { PRGF } & 4 / 10 / 2002 & 4 / 09 / 2005 & 8.64 & 6.15\end{array}$

Stand-By
Arrangement
02/20/1998
$03 / 15 / 2000$
2.50
0.00

VI. Projected Obligations to Fund (SDR million; based on existing use of resources and present holdings of SDRs):

\begin{tabular}{lccccc} 
& \multicolumn{5}{c}{ Forthcoming } \\
\cline { 2 - 6 } & $\underline{2004}$ & $\underline{2005}$ & $\underline{2006}$ & $\underline{2007}$ & $\underline{2008}$ \\
Principal & 0.00 & 0.00 & 0.00 & 0.12 & 0.49 \\
Charges/interest & 0.01 & 0.04 & 0.04 & 0.04 & 0.04 \\
Total & 0.01 & 0.04 & 0.04 & 0.17 & 0.53
\end{tabular}

\section{Safeguards Assessments:}

Under the Fund's safeguards assessment policy, the Bank of Cape Verde (BCV) is subject to an assessment with respect to the PRGF arrangement approved on April 10, 2002. A safeguards assessment of the BCV was completed on December 9, 2002. The assessment identified certain vulnerabilities in the reporting, internal control, and audit areas, and made appropriate 
recommendations, as reported in Country Report 03/152 (6/13/03). The BCV has implemented all but one of the safeguards assessment recommendations. The one outstanding recommendation, regarding clear separation of front and back office functions in the Operations Division, is expected to be implemented in early 2005 .

\section{Exchange Arrangements:}

The currency of Cape Verde, the Cape Verde escudo, was pegged to the Portuguese escudo from mid-1998 to end-1998, and from January 4, 1999 it has been pegged to the Euro, at a rate of CVEsc 110.27 per EUR 1. There are no taxes or subsidies on purchases or sales of foreign exchange. There are no arrangements for forward cover against exchange rate risk operating in the official or the commercial banking sector.

\section{Article IV Consultation:}

Discussions for the 2002 Article IV consultation and the first review under the PRGF arrangement were held in Praia during October 13-27, 2002. The Executive Board concluded the discussions of the Article IV consultation and completed the first review under the PRGF on December 16, 2002 (Country Report No. 03/152; 6/13/03). The Article IV consultation is now held on a 24-month cycle, subject to the provisions of the decision on consultation cycles approved on July 15, 2002. The previous Article IV consultation discussions were held in Praia during the period March 3-16, 2001. The Executive Board approved its conclusion on June 15, 2001 (Country Report No. 01/174; 10/03/01). It is expected that the next Article IV consultation with Cape Verde will be held in March 2005.

\section{Technical Assistance:}

Since 1985, the Fund has provided technical assistance to both the Bank of Cape Verde and to the Ministry of Finance in several areas: (i) the Bank of Cape Verde has received technical assistance from MFD, in organization and methods, management of external debt, monetary and banking statistics, accounting, credit, and foreign exchange operations, management of public debt, and the separation of the functions of the Bank of Cape Verde, as well as on the choice of exchange rate regime; (ii) the Ministry of Finance has received technical assistance from FAD, in organization and budgetary procedures, budgeting, tax policy, and tax administration; and (iii) STA missions have aimed at improving the money and banking, balance of payments, national accounts, and general statistics (Cape Verde is a participant in the GDDS Regional Project for Lusophone Africa). Most recently, the following steps have been taken:

- In July 2003, an MFD expert visited the Bank of Cape Verde to advise on safeguards issues.

- The most recent technical assistance mission on balance of payments statistics was conducted during August 26-September 6, 2002.

- An FAD mission, in June-July 1999, and an advisor (resident from March 2000December 2002 and peripatetic since then) have been advising the authorities on the 
rationalization of the import tariff and the overhaul of the domestic indirect tax system, including the January 2004 introduction of a value-added tax (VAT).

- In October 2004, two FAD missions visited Cape Verde - one to review tax administration, including VAT implementation, the other to assist the assessment of tax exemptions and incentives.

XI. Resident Representative: None 


\section{Cape Verde: Relations with the World Bank}

(As of November 30, 2004)

\section{Partnership in Cape Verde's development strategy}

1. The government of Cape Verde's development strategy is set forth in the interim poverty reduction strategy paper (I-PRSP) (www.imf.org). The I-PRSP focuses on promoting governance, entrepreneurial capacity, competitiveness, and growth; developing human capital through the education and training system; promoting social development, combating poverty, and strengthening cohesion and solidarity; and developing basic and economic infrastructure. The authorities have submitted their final PRSP and the JSAN is currently planned for Board presentation in January 2005.

\section{World Bank Group strategy}

2. The objective of the World Bank Group's assistance strategy is to help Cape Verde reduce poverty by supporting the government's PRSP. The Bank has engaged the government in a dialogue on budget support, on the basis of sector programs presented in the forthcoming PRSP. The Bank's current strategic focus supports efforts in the areas of (i) macroeconomic management and institutional capacity building; (ii) policy reforms in support of private sector development; and (iii) human resource development and poverty reduction. Bank-supported interventions aim at broadening the basis of private sector participation in Cape Verde's economy and enhancing private sector competitiveness. Components of the strategy include the following: improving the investment climate; building institutional capacity; implementing pension reforms; and modernizing and restructuring the financial sector.

\section{World Bank Group activities and assessment of country policies}

\section{IDA portfolio}

3. The current World Bank portfolio gives a high priority to capacity building in the social, public, and infrastructure sectors, and to the careful introduction of market-based incentives for private sector development. These central themes have also been identified in the country's PRSP as key pillars on which to base the future of the country's development strategy.

4. In strengthening the country's physical infrastructure, a proposed Road Sector operation is under preparation. The Energy/Water Project aims to improve the supply of power, water, and sanitation systems, to increase operational and end-use efficiency in the power and water sectors, to lower the barriers to the development of renewable energy sources, and to foster the sound management of water resources. The Privatization Project is developing local capacity to design and implement reforms in the public enterprise sector, monitor performance, and build private sector capacity through training. The Growth and Competitiveness Project supports the private sector development strategy. 
5. In the social sectors, the Social Sector Development Supplemental Credit supports poverty reduction for the 30 percent of the population living below the poverty line by (i) assisting the government in restructuring the labor-intensive public works program (FAIMO) by creating an institutional capacity (AGECABO) to execute public works; (ii) strengthening the capacity of municipalities, communities, and nongovernmental organizations (NGOs) in carrying out cost-effective poverty alleviation interventions; and (iii) establishing a central capacity to coordinate, monitor, and evaluate the poverty alleviation programs. An HIV/AIDS project went into effect in 2002. The credit supports (i) mitigation of the health and socioeconomic impact of HIV/AIDS at individual, household, and community levels, thus sustaining an economically productive population, and (ii) establishment of a strong and sustainable national capacity to respond to the epidemic.

6. The Bank's medium-term approach will selectively identify some of its programs for focused assistance and advice. Financial support is expected to take the form of a Poverty Reduction Support Credit (PRSC - currently under preparation), which will provide budgetary support on the basis of an agreed reform program. The World Bank, IFC, and MIGA will continue to coordinate their respective roles to support development activities in Cape Verde.

\section{Assessment of country policies}

7. The authorities of Cape Verde and development partners, including the Bank, have undertaken a substantial body of analytic work over the past two years to assess key social, structural, and sectoral development policies and identify policy and institutional reform priorities for poverty reduction. Regarding strategic policymaking, the Bank has provided advice on the I-PRSP and sector strategies.

8. In the area of public sector management, the authorities have sought partners' advice on strengthening the administration's capabilities. In that connection, the Bank has produced a study on the role of the state and a public expenditure review, is leading a study of the pension system, has participated in a Country Financial Accountability Assessment (along with the Netherlands and the European Union) and is carrying out an assessment of the procurement mechanisms of the state, and supporting important statistical work (such as a household survey).

9. As of November 30, 2004, IDA had extended 21 credits to Cape Verde, amounting to about US $\$ 198$ million equivalent, of which about US\$173 million equivalent has been disbursed. Fifteen credits have closed, and the current portfolio includes six credits, with associated credit amounts of about US\$67 million equivalent and an undisbursed balance of about US\$26million. The involvement of the International Finance Corporation (IFC) in Cape Verde is limited.

\section{World Bank-Fund collaboration in specific areas}

10. The Fund and the Bank continue to collaborate in many areas, including fiscal operations and tax reform; public enterprise reform and privatization; utility regulation and private sector development; and the strengthening of human resource development and the poverty reduction strategy. In close collaboration with the World Bank, the Fund staff has discussed and reached understandings on a structural reform program with the government of Cape Verde in the context of 
the PRGF arrangement. The Fund and the Bank have collaborated in the areas of the privatization program, utility regulation, public expenditure management, and civil service and pension system reform.

11. Questions may be referred to Mr. Madani M. Tall (tel.: 1-221-849-5011), Ms. Francoise Perrot (Tel: 1-202-0473-4465), or Mr. Jean van Houtte (Tel.: 1-202-473-0156).

\section{Statement of IDA Operations}

(As of November 30, 2004; in millions of U.S. dollars)

\begin{tabular}{|c|c|c|c|c|c|c|}
\hline $\begin{array}{c}\text { Credit } \\
\text { No. }\end{array}$ & Projects & $\begin{array}{c}\text { Principal } \\
\text { Amount }\end{array}$ & Disbursed & $\begin{array}{c}\text { Undisbur- } \\
\text { sed }\end{array}$ & $\begin{array}{c}\text { Approved } \\
\text { Date }\end{array}$ & $\begin{array}{c}\text { Closing } \\
\text { Date } \\
\end{array}$ \\
\hline & 13 credits closed & 130.8 & 128.6 & 0.2 & & \\
\hline 32241 & Social sector development supplem. & 4.0 & 1.9 & 2.4 & 16-Dec-03 & 31-Mar-05 \\
\hline 37550 & growth \& competitiveness & 11.5 & 1.8 & 11.1 & 13-May-03 & $28-F e b-08$ \\
\hline 36290 & HIV/AIDS & 9.0 & 7.4 & 3.3 & 28-Mar-02 & 31-Dec-06 \\
\hline 31210 & Privatization technical assistance & 9.0 & 8.2 & 1.1 & 21-Jul-98 & 31-Dec-04 \\
\hline 32050 & Energy/water & 17.5 & 10.0 & 7.8 & 11-May-99 & 30-Jun-04 \\
\hline \multirow[t]{3}{*}{32240} & Social sector development & 16.1 & 15.6 & 0.2 & 25-May-99 & 31-Mar-05 \\
\hline & Total active projects & 67.1 & 44.9 & 26.0 & & \\
\hline & Active and closed projects & 197.9 & 173.5 & 26.2 & & \\
\hline
\end{tabular}

Note: Disbursed amount may be higher than commitment (approved amount) due to exchange rate vis-à-vis SDR.

\section{Statement of IFC Investments}

(In millions of U.S. dollars)

Original Gross Commitments Disbursed

\begin{tabular}{|c|c|c|c|c|c|c|c|c|c|c|}
\hline \multirow[b]{2}{*}{$\begin{array}{c}\text { FY } \\
\text { Approv. }\end{array}$} & \multirow[b]{2}{*}{ Company } & \multirow[b]{2}{*}{$\begin{array}{l}\text { Type of } \\
\text { Business }\end{array}$} & & \multirow[b]{2}{*}{ Loan } & \multirow[b]{2}{*}{ Equity } & \multirow[b]{2}{*}{ Quasi } & \multirow[b]{2}{*}{ Partic } \\
\hline & & & Loan & Equity & Quasi & Partic & & & & \\
\hline 1992 & Growela 1/ & $\begin{array}{l}\text { Shoe manu- } \\
\text { facturing }\end{array}$ & 0.15 & 0.00 & 0.00 & 0.00 & 0.15 & 0.00 & 0.00 & 0.00 \\
\hline 2001 & Moura 2/ & Transport & 0.63 & 0.00 & 0.00 & 0.00 & 0.00 & 0.00 & 0.00 & 0.00 \\
\hline \multicolumn{3}{|c|}{ Total portfolio } & 0.78 & 0.00 & 0.00 & 0.00 & 0.15 & 0.00 & 0.00 & 0.00 \\
\hline
\end{tabular}

$1 /$ Growela $=$ shoe manufacturing.

2/ Moura $=$ public transportation. 
January 13,2005

Mr. Rodrigo de Rato

Managing Director

International Monetary Fund

Washington, D.C. 20431

U.S.A.

Dear Mr. Rato:

1. On April 10, 2002, the Executive Board of the IMF approved a three-year arrangement for Cape Verde under the Poverty Reduction and Growth Facility (PRGF) in the amount of SDR 8.64 million (90 percent of quota). The purpose of this letter is to inform you of the progress in implementing the third-year economic program, and to request the sixth loan disbursement upon completion of the fifth review under the arrangement.

2. The attached memorandum of economic and financial policies (MEFP) supplements the MEFPs of March 11, 2002; December 6, 2002; June 9, 2003; December 2, 2003, and July 23, 2004. It sets out the objectives and policies the government of Cape Verde will pursue during the remainder of 2004 and in the first half of 2005.

3. Cape Verde's economic performance through September 2004 was in line with the PRGF arrangement. All performance criteria and indicative targets for end-June 2004 and end-September 2004 were observed, as were most structural performance benchmarks. As signaled in the previous review, there have been some delays concerning benchmarks on the completion of an assessment on tax exemptions and on the adoption of regulations for determining electricity and water tariffs, owing to the difficulties in finding consultants to conduct this work. However, the assessment of tax exemptions has recently been completed and regulations for tariff adjustments are expected by end-December 2004. In addition, consultants have recently been engaged to help resolve the complex financial relationship between the government and Electra (the water and power company).

4. The government believes that the measures it has taken and the policies it intends to pursue in 2005 (as described in the attached MEFP) will help to establish the conditions for achieving a high rate of sustainable economic growth and a reduction in poverty. On this basis, the government of Cape Verde requests the completion of the fifth review under the arrangement. The government also requests a short extension of the arrangement to endJuly 2005 to provide sufficient time for the completion of the final review and for the final disbursement.

5. Looking ahead, the government is determined to maintain its excellent working relationship with the IMF. It will seek to reach agreement with the Fund over the next few months on what form of financial arrangement with the Fund would be most appropriate following the end of the current PRGF arrangement. In these discussions, the government's 
policy program will continue to be directed toward ensuring macroeconomic stability, debt sustainability, and support for the PRSP.

6. The government believes that the measures and policies set forth in the attached memorandum are adequate to achieve its program objectives, but will take any further actions that may prove necessary for this purpose. For as long as Cape Verde has outstanding financial obligations to the Fund arising from the loans under the arrangement, the government will consult with the Fund, at the initiative of the government or whenever the Managing Director requests consultation, on Cape Verde's economic and financial policies.

7. The government authorizes the Fund to provide this letter, the attached memorandum, and the associated staff report to all interested parties that request them, including through the Fund's external website.

Sincerely yours,

$/ \mathrm{s} /$

$\frac{1 / \mathrm{s} /}{\text { João Serra }}$

Attachments: Memorandum of Economic and Financial Policies

Technical Memorandum of Understanding

Washington, D.C. 2 


\section{CAPE VERDE}

\section{Supplementary Memorandum of Economic and Financial Policies}

FOR NOVEMBER 2004-APRIL 2005

\section{INTRODUCTION}

1. Cape Verde's ongoing program of economic stabilization and reform is being supported by a three-year arrangement under the Poverty Reduction and Growth Facility (PRGF) which began in April 2002. Consistent with the goals set out in our memorandum of economic and financial policies dated March 11, 2002, and updated most recently on July 23, 2004, this supplementary memorandum reviews the implementation of the program through September 2004, and sets out the government's policies through the end of the program in 2005 .

\section{EConomic ANd Policy Developments through SePtember 2004}

2. Economic performance through September 2004 was broadly in line with the program. Some recent developments have caused real growth projected for 2004 to slow to about 4 percent relative to the 5.5 percent originally expected, but these influences are expected to be short-lived. In particular, agricultural output has been negatively affected by poor rainfall and a locust infestation; execution of the public investment program has been lower than expected; and tourism appears to have slowed slightly relative to 2003 . As in other oil-importing countries, economic activity has also been adversely affected by the impact of higher international oil prices.

3. Inflation remained subdued through October 2004, with annual inflation likely to reach only about 1.5 percent over the year. Strong agricultural performance in the 2003-2004 season helped to lower food prices, with further downward pressure on prices coming from reductions in customs tariffs at the beginning of the year. While the impact of higher oil prices has been dampened by constant energy prices for domestic consumers and by the weaker U.S. dollar, retail fuel tariffs were adjusted in June and November to reflect higher international prices.

4. The fiscal program is on track. Preliminary data indicate that revenues increased by about half a percent of GDP in the first half of 2004 relative to the same period a year earlier. Higher-than-expected revenues from the new value-added tax (VAT) and from nontax revenues more than offset lower revenues from international trade taxes (reflecting reforms to customs tariffs and excises). VAT collections during the first six months of 2004 stand at about 60 percent of the total projected for the year. Revenue performance is expected to improve further once the VAT is fully operational, so that VAT collections for the whole year may be substantially above initial expectations. On the expenditure front, the wage bill has been contained and is on track to meet the program target for the end of the year. All other spending items are considerable below their levels for the same period in 2003 (in percent of GDP). As noted above, the capital investment program has moved 
slowly, with the low pace of execution associated with administrative delays in managing the programming cycle. These delays slowed the pace of disbursements for many projects, including from the World Bank and the European Union.

\section{In 2004, Cape Verde has implemented the most comprehensive fiscal reform in} its history. These measures have encompassed a rationalization and reduction of taxes on imports, and substitution of an inefficient sales taxes for a modern VAT. Significant progress has also been achieved in implementing structural reforms to strengthen fiscal management. A VAT Service and Information Unit to assist taxpayers to comply with the new law is now fully functional, and VAT processing offices in charge of registering taxpayers, receiving tax forms, and compiling data are also fully functional in four main districts, with more than 9,000 taxpayers already registered in the system.

\section{Monetary developments through September 2004 were in line with the}

program. Net international reserves (NIR) of the Bank of Cape Verde (BCV) continued to rise, reaching $€ 89.5$ million (equivalent to 2.2 months of imports). Growth of credit to the economy slowed slightly compared to 2003, reflecting in part the slowdown in economic activity and high domestic lending rates of commercial banks. Broad money increased by 11.2 percent year-on-year in September, although some deceleration appears to have occurred in the fourth quarter.

7. Cape Verde has observed all the quantitative and structural performance criteria for end-June 2004, and all but three structural performance benchmarks for end-June and end-September 2004. An assessment of the costs of tax exemptions and incentives was delayed owing to the difficulty of finding an appropriate consultant for this study. Following our request for technical assistance from the IMF, a mission visited Praia in October to conduct this assessment. In addition, as signaled in the fourth review of the program, the benchmark on the adoption of regulations for the methodology to determine electricity and water tariffs at the independent Economic Regulatory Agency (ARE) has been delayed to December 2004, with the World Bank assisting ARE in the preparation of this methodology.

\section{The government has made progress in identifying and settling old domestic} arrears and previously disputed claims. It has cleared its arrears to Electra (the electricity and water utility) on its consumption of water and electricity, and has initiated an arbitration process with Electra to identify the government's liabilities (which had been an endSeptember benchmark). ${ }^{1}$ These include obligations arising from the non-adjustment of electricity tariffs during 2000-2002 when world oil prices increased significantly. Once the arbitration process is concluded, the government will agree on a payment plan that will cover its remaining liabilities to Electra. In addition, the government has cleared arrears

\footnotetext{
${ }^{1}$ The World Bank is providing technical assistance for this project.
} 
with Cape Verde Telecom and Shell Oil company, and is in the process of clearing arrears with other suppliers.

9. In February 2004, ARE implemented a mechanism to adjust retail gasoline and diesel prices according to changes in import prices of oil products. Following a first round of price changes in June 2004 under the new mechanism, the subsequent adjustment did not occur until November as a result of some difficulties that ARE encountered in implementing the mechanism, including in its negotiations with oil suppliers. ARE expects that more frequent and systematic price adjustments will occur from January 2005 as these difficulties are resolved.

\section{The Program for NoveMber 2004-APRIL 2005}

\section{Our key macroeconomic objectives for 2004-05 are set out in the following} table:

\begin{tabular}{|c|c|c|c|c|}
\hline \multicolumn{5}{|c|}{ Cape Verde: Key Macroeconomic Objectives } \\
\hline & $\begin{array}{l}2002 \\
\text { Prel. }\end{array}$ & $\begin{array}{l}2003 \\
\text { Prel. }\end{array}$ & $\begin{array}{l}2004 \\
\text { Proj. }\end{array}$ & $\begin{array}{l}2005 \\
\text { Proj. }\end{array}$ \\
\hline & \multicolumn{4}{|c|}{ (In percent, unless otherwise indicated) } \\
\hline Real GDP growth & 5.0 & 5.3 & 4.0 & 6.0 \\
\hline Inflation (period average) & 1.8 & 1.2 & -1.6 & 2.0 \\
\hline Broad money growth & 14.3 & 8.6 & 8.2 & 8.6 \\
\hline Credit to the economy growth & 12.0 & 15.4 & 9.7 & 8.3 \\
\hline $\begin{array}{l}\text { Growth of banking system net credit to } \\
\text { government/GDP }\end{array}$ & 3.6 & 1.1 & 0.5 & 0.1 \\
\hline Revenue/GDP & 22.1 & 21.3 & 23.7 & 23.7 \\
\hline Expenditure/GDP & 33.0 & 29.9 & 32.3 & 31.5 \\
\hline Fiscal deficit including grants/GDP & -2.5 & -3.2 & -2.9 & -3.7 \\
\hline Current account balance including grants/GDP & -11.0 & -9.2 & -7.8 & -8.2 \\
\hline Reserves/Imports (months) & 2.0 & 1.9 & 2.2 & 2.4 \\
\hline
\end{tabular}

\section{A. Growth and Inflation}

11. Real growth is projected to reach 6 percent in 2005 , owing largely to strong growth projected for the tourism sector and increased public investment. The completion of the new international airport in Praia, the construction and improvement of airports in Boa Vista and Sao Vicente, as well as the completion of a large hotel on Sal, should support increased tourist traffic and local commerce. Project financing from donors

Washington, D.C. 2 
will be channeled into public and social investment initiatives, including projects set out in the PRSP, and some projects that were not executed in 2004 will carry over to 2005. The government also intends to attract foreign direct investment and to spur export activity through a newly established free trade zone and the completion of an industrial park in Mindelo.

12. Inflation is likely to be around $\mathbf{2}$ percent in $\mathbf{2 0 0 5}$ (on an annual average basis), influenced primarily by higher food prices caused by poor agricultural performance in 2004 and increases in domestic energy prices arising from higher international oil prices. The measurement of domestic price movements will also be improved through changes in the methodology for calculating the CPI.

\section{B. Fiscal Policy}

13. The fiscal program through April 2005 reaffirms the government's commitment to maintain macroeconomic stability and pursue the investment agenda laid out in our recent Poverty Reduction Strategy Paper (PRSP), while providing the necessary support to build up international reserves to sustain the exchange rate peg. Performance for the first four months of 2005 will be in line with a primary recurrent surplus of 5 percent of GDP projected for the whole year. Domestic revenue is projected to reach nearly 24 percent of GDP, reflecting efficiency gains in the VAT, strong growth in import-based taxes (including the VAT), the elimination of exemptions to the previous consumption tax, and the incorporation of the budgets of autonomous agencies into the national budget. Total expenditure will be contained at 31.5 percent of GDP, stemming from prudent expansion of wages and salaries and a strategic approach to capital spending, focusing on PRSP priorities. Net official financing (including grants) already committed and a modest amount of domestic bank financing will enable the government to clear the remaining domestic arrears by about 0.5 percent of GDP.

14. We will focus our efforts on implementing a strategic plan for strengthening tax administration, following the recommendation of a recent mission from the Fund's Fiscal Affairs Department (FAD). Given the introduction of the VAT and the new import tariff structure, the government does not intend to introduce any new taxes in 2005 . We are in the process of implementing a strategy to modernize domestic revenue administration by improving its organization and operations, and by securing improvements in work processes, management, and services. Drawing on recommendations of the FAD mission, the introduction of all VAT returns into the VAT computer system by December 2004, and implementation of new rules for tax collections through the commercial banks by February 2005, will be structural benchmarks under the program.

\section{Monetary and Financial Sector Policies}

15. The BCV's monetary policy in $\mathbf{2 0 0 5}$ will continue to be oriented toward maintaining price stability and accumulating international reserves. These policy objectives are necessary for sustaining the exchange rate peg and market confidence.

Washington, D.C. 2 
Growth of broad money and of credit to the economy is projected to be 8-9 percent in 2005, consistent with nominal GDP growth.

16. The $\mathrm{BCV}$ is working toward the introduction of indirect monetary policy instruments, which would enhance competition in the banking sector. We intend to request technical assistance from the Monetary and Financial Systems Department to support the development of a comprehensive strategy in this area. The BCV will assess the scope for reducing unremunerated reserve requirements for commercial banks (currently at 19 percent) while improving management of banks' liquidity.

17. The BCV recognizes that continued fiscal prudence to minimize government recourse to domestic bank credit is essential for reducing key interest rates. The BCV's efforts to lower reserve requirements, together with donor-supported programs to improve commercial banks' ability to assess project risks, will allow commercial banks to reduce the costs of financial intermediation. The regional chambers of commerce, with donor assistance, are helping their members strengthen financial transparency, which will improve their prospects for gaining access to commercial bank credit. Finally, the government and the $\mathrm{BCV}$ will continue monitoring the financial system and strengthening banking supervision.

\section{Enterprise Reform}

18. Private sector-led economic growth is a crucial component of Cape Verde's poverty reduction strategy and external viability. Critical to this element of the strategy is the reform of large public service enterprises that are either owned or regulated by the state.

19. In this regard, the government is taking steps to address past and current difficulties arising from its complex financial relationship with Electra:

- The government has recently engaged consultants to support a negotiated settlement of the government's accumulated liabilities to Electra.

- The government has requested that Electra provide data to identify separately the diesel consumption of electricity generation plants in the main urban areas as opposed to those in rural areas. With this information, the government intends that diesel subsidies be targeted on poorer rural households and funded by urban consumers, so that there would be no overall budgetary subsidy to Electra.

- The government will remain current in its payments to Electra for the government sector's consumption of electricity and water.

- $\quad$ By end-December 2004, the Board of ARE will approve an automatic and transparent mechanism for adjusting electricity and water tariffs on the basis of costs, which will be published in the official gazette (a performance criterion).

Washington, D.C. 2 
20. TACV's financial performance has improved over the past year. Operating losses have been reduced and the company is meeting its current obligations, including to the airport and air navigation authority for operating expenses and passenger fees. A new management team will take control of TACV in January 2005, with the aim of restructuring the company and streamlining operations in preparation for privatization, which is expected to take place in early-2006.

21. The remaining public enterprises scheduled for privatization-Arca Verde, CABNAVE, EMPROFAC, ENAPOR, and Interbase-remain on track to be transferred from government ownership or to allow for private concession contracts by end-2005. The development of regulatory capacity to cover the privatized industries and sectors is proceeding in tandem with the privatization process.

\section{The PRSP ANd Medium-Term Macroeconomic ObJectives ANd Strategy}

22. The recently presented PRSP contains the foundations of Cape Verde's strategy to enhance growth and alleviate poverty. The document was widely discussed with different sectors of society and reflects a consensus view on how to unleash the country's potentials. Our strategy is based on the following pillars:

- $\quad$ promoting good governance, reinforcing effectiveness, and guaranteeing equity;

- $\quad$ fostering competitiveness to enhance economic growth and employment creation;

- $\quad$ developing and upgrading human capital;

- $\quad$ improving and developing basic infrastructure, promoting land use management, and protecting the environment;

- $\quad$ improving the effectiveness and sustainability of the social protection system.

23. In support of the PRSP, the government has begun to develop a medium-term expenditure framework for 2005-07 with assistance from our development partners. The key macroeconomic assumptions underpinning this framework are broadly consistent with those of the PRGF arrangement: (i) real GDP growth on the order of 5 to 7 percent; (ii) inflation of around 2 percent; and (iii) a gradual increase in gross international reserves to the equivalent of $2 \frac{1}{2}-3$ months of imports of goods and services by end-2007. Broad money is projected to grow broadly in line with nominal GDP, and credit to the economy would need to grow somewhat more rapidly to provide the necessary support to the private sector. The government anticipates the need for additional budget support during this period and will convene a donor conference in the first half of 2005 to seek the support of our development partners. The priorities of the investment plan of the government are fully aligned with the PRSP.

Washington, D.C. 2 


\section{Program Monitoring}

24. Program implementation through the end of the current PRGF arrangement will be monitored according to the performance criteria and benchmarks presented in Tables 1 and 3. The definition of the variables monitored as quantitative performance criteria and benchmarks and reporting requirements are set out in the attached technical memorandum of understanding (TMU). The TMU is unchanged from that of the fourth review of the PRGF. As noted in the Letter of Intent, the government requests a short extension of the arrangement to end-July 2005 to provide sufficient time for the sixth review and final disbursement. 
Table 1. Cape Verde: Quantitative Performance Criteria and Benchmarks for 2004-05 Under the PRGF Arrangement 1/ 2/

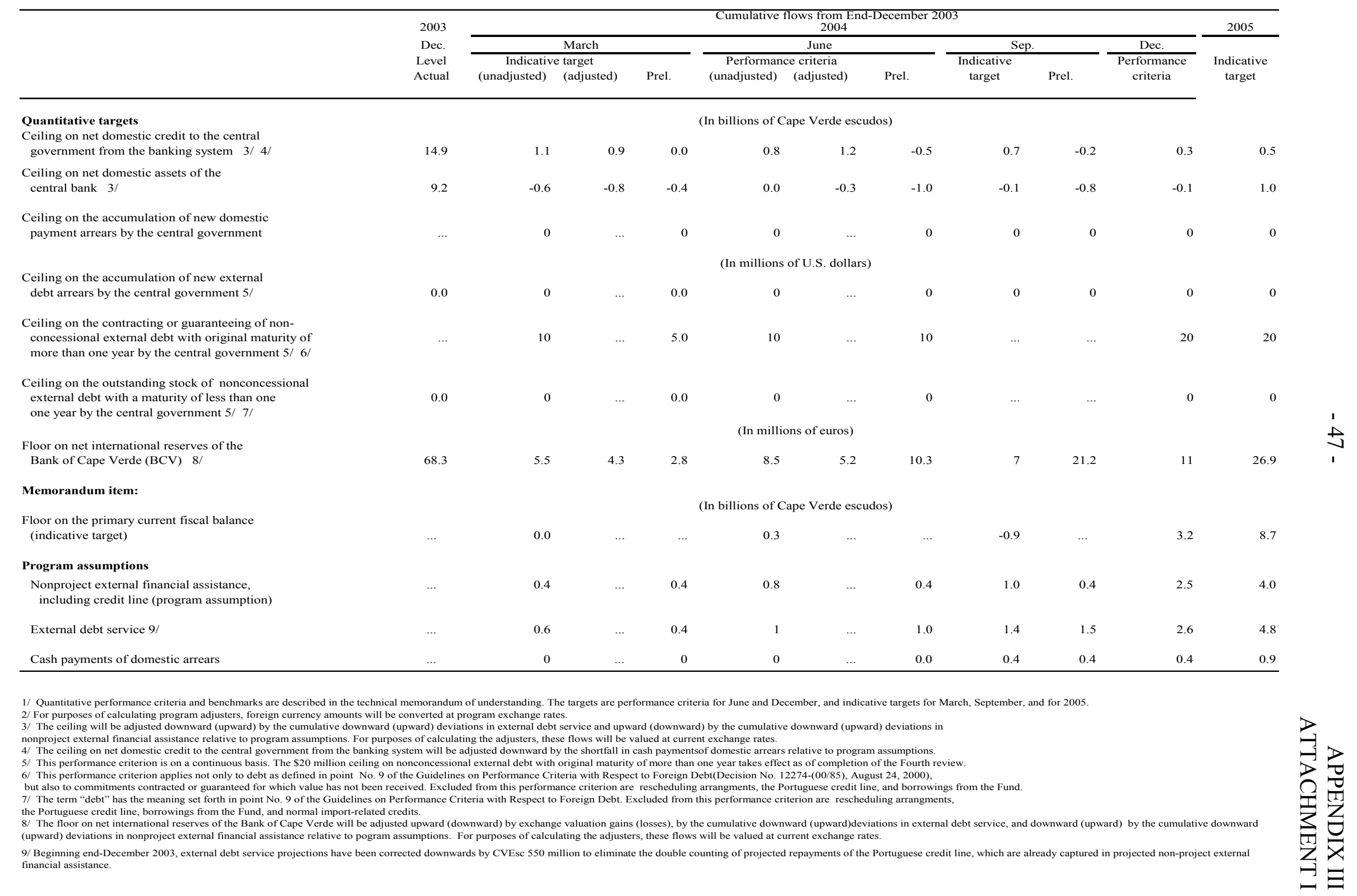

CInternational Monetary Fund. Not for Redistribution 
Table 2. Cape Verde: Structural Performance Criteria and Benchmarks Under the Third Annual Program Supported by the PRGF Arrangement

\begin{tabular}{lll}
\hline Measures & Test Dates & $\begin{array}{l}\text { Status or Amended } \\
\text { Test Dates }\end{array}$ \\
\hline
\end{tabular}

\section{Structural performance criteria}

Refrain from providing budgetary subsidy to Electra Continuous Observed. until MOU on monitoring signed.

Refrain from providing budgetary subsidy to TACV. Continuous Observed.

\section{Structural benchmarks}

Complete comprehensive assessment of the cost of June 2004 all tax exemptions and incentives.

Assessment conducted in November, 2004.

Adopt regulations establishing the methodology for June 2004 determining electricity and water tariffs at the Economic Regulatory Agency.

Still in preparation. Implementation delayed to endDecember.

Submit report of fiscal operations for the first quarter of 2004 to the National Assembly.

June 2004

Observed.

Establish VAT Service and Information Unit.

September 2004 Observed.

Conclude report on government's financial liabilities to Electra.

September 2004 Negotiations with Electra under way.

Present report on fiscal operations in the first half of 2004 to the National Assembly.

September 2004 Observed. 
Table 3. Cape Verde: Supplementary Structural Performance Criteria and Benchmarks Under the Third Annual Program Supported by the PRGF Arrangement

\begin{tabular}{ll}
\hline \multicolumn{1}{c}{ Measures } & Test Dates \\
\hline Structural performance criteria & \\
$\begin{array}{l}\text { Refrain from providing budgetary subsidy to Electra for current } \\
\text { operating expenses. }\end{array}$ & Continuous. \\
$\begin{array}{l}\text { Refrain from providing budgetary subsidy to TACV for current } \\
\text { operating expenses. }\end{array}$ & Continuous. \\
$\begin{array}{l}\text { Approval by the Board of the ARE of an automatic and } \\
\text { transparent mechanism for adjusting electricity and water tariffs } \\
\text { on the basis of costs, and publication of such mechanism in the } \\
\text { official gazette. }\end{array}$ & End-December 2004. \\
$\begin{array}{l}\text { Structural benchmarks } \\
\text { Establish VAT processing offices in four main districts. 1/ }\end{array}$ & End-December 2004. \\
$\begin{array}{l}\text { Present budget incorporating reduction of tax exemptions to the } \\
\text { National Assembly. }\end{array}$ & End-December 2004. \\
$\begin{array}{l}\text { Introduction of all VAT returns into the VAT computer system. } \\
\text { Implementation of new rules for tax collections through } \\
\text { commercial banks. }\end{array}$ & End-December 2004. \\
\hline
\end{tabular}

1/ As noted in the MEFP, this benchmark has already been met.

Washington, D.C. 2 


\section{CAPE VERDE}

\section{Technical Memorandum of Understanding}

1. This memorandum sets out the understandings between the Cape Verdean authorities and the IMF staff regarding the definition of the quantitative performance criteria and indicative targets and reporting requirements under the second annual program supported by the Poverty Reduction and Growth Facility (PRGF) arrangement.

\section{Quantitative Performance Criteria And Indicative Targets ${ }^{12}$}

\section{A. Government Finances}

2. Total government revenue is defined as the sum of all tax and nontax revenues, domestic capital participation, and net lending, cumulative since the start of the calendar year, excluding privatization proceeds and external grants. Tax revenue and nontax revenue are defined in accordance with the Government Finance Statistics Manual (GFS) 1986, Section IV.A.1.

3. The floor on the primary current fiscal balance cumulative from the beginning of calendar-year 2004 constitutes an indicative performance target. The primary current fiscal balance is defined as the difference between total government revenue (defined above in para. 1) and current primary expenditures on a commitment basis. Current primary expenditures equal total government expenditures on a commitment basis less interest obligations on external and domestic debt, capital expenditures, extraordinary expenditures on social emergency measures, and retrenchment payments made as part of the public enterprise privatization and liquidation reform.

4. For the purposed of this memorandum, privatization proceeds will be understood to mean all monies received by the government from the sale or concessioning of a public company, organization, or facility to a private company or companies, organization(s), or individual(s), as well as any proceeds generated from the liquidation of a public company, less restructuring costs.

5. Reporting requirements. Data on the implementation of the budget compiled by the Ministry of Finance and Economic Planning will be provided on a quarterly basis, to be

\footnotetext{
${ }^{1}$ See Table 1 of the memorandum on economic and financial policies (MEFP).

2 The data source used to evaluate the performance criteria on net domestic credit to the central government, net domestic assets of the central bank, and net international reserves will be the Cabo Verde-Panorama Bancario tables prepared monthly by the Bank of Cape Verde (BCV) Statistics and Research Department and forwarded electronically to the IMF African and Statistics Departments.
} 
submitted not later than five weeks after the end of each quarter, including (i) government revenue by category, including external budget support grants; (ii) government expenditure, including primary current expenditure, domestic and external interest payments, and capital expenditure, including domestic capital expenditure and estimates of externally financed capital expenditure; (iii) the gross payment and gross accumulation of domestic payments arrears; (iv) external loan receipts and principal payments; (v) external arrears payments and accumulation; (vi) bank and nonbank financing; (vii) privatization receipts; and (viii) any other revenue, expenditure, or financing not included above.

\section{B. Net Domestic Assets of the Central Bank}

6. The ceiling on the cumulative change, from the beginning of calendar-year 2004, in net domestic assets of the Bank of Cape Verde (BCV) constitutes a performance criterion. Net domestic assets (NDA) of the $\mathrm{BCV}$ are defined as reserve money minus net foreign assets of the $\mathrm{BCV}$, evaluated at the program exchange rates presented below. The program ceilings for NDA will be adjusted downward (upward) by the cumulative downward (upward) deviations in external debt service and upward (downward) by the cumulative downward (upward) deviations in nonproject external financial assistance relative to program assumptions. For purposes of calculating the adjusters, these flows will be valued at current exchange rates. Reserve money comprises bank reserves and deposits of the monetary institutions and private sector with the central bank, as well as cash in circulation.

7. Reporting requirements. The preliminary monthly balance sheets of the BCV and the consolidated commercial banks will be transmitted on a monthly basis, with a maximum delay of five weeks. The definitive version of the monthly balance sheet of the BCV will be provided as soon as available.

\section{Net Bank Credit to the Central Government}

8. The ceiling on the cumulative change, from the beginning of calendar-year 2004, in net credit to the central government from the banking system constitutes a performance criterion. Net credit to the central government from the banking system (NCCG) is defined as the overall position of the main central government institutions vis-à-vis the banking system - that is, the stock of all outstanding claims on the central government (loans, advances, and all other government debt instruments, such as long-term government securities) held by the central bank and by commercial banks, less all deposits held by the central government with the central bank and with commercial banks, as they are reported monthly by the BCV to the IMF. The INPS (the social security agency) is not included in central government accounts. Net bank credit to the central government excludes claims on the Trust Fund (TCMFs).

9. Claims on the central government held by the central bank comprise the following items: (i) crédito conta corrente OGE; (ii) Tesouro público protocolo; (iii) títulos governo central—obrigações nova serie; (iv) créditos a regularizar $\mathrm{m} / \mathrm{n}$ e $\mathrm{m} / \mathrm{e}$; (v) outros créditos ao 
governo; and (vi) any other claims, or claims on the central government to be regularized, held by the central bank.

10. Deposits held by the central government with the central bank comprise the following items: (i) depósitos do governo central - depósitos a ordem $\mathrm{m} / \mathrm{n}$; (ii) depósitos do governo central - depósitos a ordem m/e; and (iii) outros depositos do governo central.

11. Claims on the central government held by the commercial banks comprise the following items: (i) obrigações do Tesouro; (ii) bilhetes do Tesouro; (iii) protocolos; (iv) empréstimos; (v) outros títulos; (vi) outros créditos; and (vii) any other claims, or claims on the central government to be regularized, held by the commercial banks.

12. Deposits held by the central government with the commercial banks comprise the following items: (i) dep. governo central em $m / n$-D.G.T.; (ii) dep. governo central em $m / n$-serviços autónomos; (iii) dep. governo central em $m / n$-fundos autónomos; (iv) dep. governo central em $m / n$ — projectos de investimentos; (v) dep. governo central em $m / n$ fundos de contrapartida; (vi) dep. governo central em $\mathrm{m} / \mathrm{n}$-institutos clautonomia administ. e financeira excepto INPS; (vii) dep. governo central em m/e; and (viii) outros passivos com o governo.

13. The program ceilings for the NCCG will be adjusted downward (upward) by the cumulative downward (upward) deviations in external debt service and upward (downward) by the cumulative downward (upward) deviations in nonproject external financial assistance relative to program assumptions. For purposes of calculating the adjusters, these flows will be valued at current exchange rates. In addition, the ceilings for the NCCG will be adjusted downward by the shortfall in cash payments of domestic arrears relative to program assumptions.

14. Reporting requirements. The preliminary monthly balance sheets of the BCV and the consolidated commercial banks will be transmitted on a monthly basis, with a maximum delay of five weeks. The definitive version of the monthly balance sheet of the BCV will be provided as soon as available.

\section{Ceiling on Nonconcessional External Debt Contracted or Guaranteed by the Central Government}

15. Under the program, ceilings on medium- and long-term, as well as on short-term, nonconcessional external debt constitute performance criteria. These performance criteria are on a continuous basis. Nonconcessional external debt is defined as debt contracted or guaranteed by the central government with a grant element of less than 35 percent, calculated using currency-specific commercial interest reference rates (CIRRs) published by the Development Assistance Committee of the Organization for Economic Cooperation and Development (OECD). Debt rescheduling and debt reorganization are excluded from the limits on nonconcessional external debt. The limits on new nonconcessional external debt contracted or guaranteed by the central government (excluding borrowing from the Fund) are specified in Tables 1 and 3 of the memorandum of economic and financial policies. The 
definition of short-term nonconcessional external debt excludes normal short-term (less than one year) import-related financing. The Portuguese government's precautionary credit line in support of the exchange rate peg is also excluded from the definition of nonconcessional external debt. In addition, the central government will not guarantee any external debt contracted by state enterprises and will maintain the policy of not guaranteeing private sector external debt. The performance criterion on medium- and long-term nonconcessional external indebtedness applies not only to debt as defined in point No. 9 of the Guidelines on Performance Criteria with Respect to Foreign Debt (Decision No. 12274-(00/85), 8/24/00) but also to commitments contracted or guaranteed for which value has not been received. With respect to the performance criterion on short-term nonconcessional external indebtedness, the term "debt" has the meaning set forth in point No. 9 of the Guidelines on Performance Criteria with Respect to Foreign Debt (Decision No. 12274-(00/85), 8/24/00).

16. Reporting requirements. The government of Cape Verde will consult with Fund staff before assuming any liabilities in circumstances where they are uncertain whether the instrument in question falls under the performance criterion. Details of all new external debt (including government guarantees), indicating terms of debt and creditors, will be provided on a quarterly basis within five weeks of the end of each quarter.

\section{E. Net International Reserves of the Central Bank}

17. The floor on the cumulative change, from the beginning of calendar-year 2003, in net international reserves (NIR) of the BCV constitutes a performance criterion under the program. The NIR of the BCV are defined as gross international reserves of the BCV net of its short-term external liabilities, calculated at the program exchange rates described below. Gross reserves of the BCV are those that are readily available (i.e., liquid and marketable and free of any pledges or encumberments), controlled by the BCV and held for the purposes of meeting balance of payments needs and intervening in foreign exchange markets. They include gold, holdings of SDRs, the reserve position at the IMF, holdings of foreign exchange and traveler's checks, demand and short-term deposits at foreign banks abroad, fixed-term deposits abroad that can be liquidated without penalty, and any holdings of investment-grade securities. External liabilities of the BCV comprise liabilities to nonresidents contracted by the $\mathrm{BCV}$ with an original maturity of less than a year, any net offbalance-sheet position of the BCV (futures, forwards, swaps, or options) with either resident or nonresidents, any arrears on principal and interest to external creditors and suppliers, and purchases from the IMF. The program floors for the NIR will be adjusted upward (downward) by the cumulative downward (upward) deviations in external debt service and downward (upward) by the cumulative downward (upward) deviations in nonproject external financial assistance relative to program assumptions. For purposes of calculating the adjusters, these flows will be valued at current exchange rates.

18. Reporting requirements. A table on the NIR prepared by the BCV will be transmitted on weekly basis, with a maximum delay of two weeks. 


\section{F. Nonaccumulation of New Domestic Payments Arrears}

19. As part of the program, the government will not accumulate any new domestic payments arrears. This will be monitored through the monthly execution of the cash-flow plan and the corresponding release of budget appropriations. For programming purposes, a domestic payment obligation to suppliers is deemed to be in arrears if it has not been paid within the normal grace period of 60 days ( 30 days for government salaries and debt service) or such other period as has been contractually agreed with the supplier after the verified delivery of the concerned goods and services, unless the amount or the timing of the payment is subject to good faith negotiations between the government and the creditor.

20. Reporting requirements. The Ministry of Finance and Economic Planning, through the D.G.T., will submit on a quarterly basis a detailed table of the stock of domestic payments arrears, including the accumulation, payment, rescheduling and write-off of domestic payments arrears during the quarter. The data are to be provided within four weeks after the end of the quarter.

\section{G. Nonaccumulation of External Payments Arrears}

21. As part of the program, the government will not accumulate any new external payments arrears on a continuous basis. This will be monitored through the monthly execution of the cash-flow plan and the corresponding release of budget appropriations.

22. External arrears are defined as total external debt-service obligations of the government that have not been paid by the time they are due, unless the definition of an arrear has been defined contractually between the government and creditor. External arrears exclude arrears on external debt, pending the conclusion of debt-rescheduling agreements.

23. Reporting requirements. Data on (i) debt-service payments; and (ii) external arrears accumulation and payments will be transmitted on a quarterly basis by the Ministry of Finance and Economic Planning, within five weeks of the end of each quarter. In addition, the government will inform the Fund staff immediately of any accumulation of external arrears.

\section{H. Program Exchange Rates and Nonproject Budgetary Support}

24. Performance under the program will be assessed based on program exchange rates. Foreign currency amounts will be evaluated at the following program exchange rates:

CVEsc 110.3 = €1; CVEsc 87.3 = USD 1.00; and CVEsc 129.7 = SDR 1.

25. The 2004 program assumes the following nonproject budget support during 2004: (i) $€ 2.5$ million from the European Union in the third quarter of 2004 and $€ 3$ million in the fourth quarter of 2004; (ii) US\$15 million from the World Bank in the fourth quarter of 2004; (iii) US\$3.0 million from the African Development Bank, in the fourth quarter of 2004; (iv) $€ 3$ million from the Netherlands in the second quarter of 2004, as stipulated in the TMU 
for the Third Review; and (v) the repayment during the first quarter of 2004 of the outstanding $€ 1$ million from the Portuguese credit facility drawn in 2003 and the drawing of $€ 5$ million from the Portuguese credit facility in the first quarter of 2004, as stipulated in the TMU for the Third Review; $€ 4$ million of the Portuguese credit line drawings will be repaid in the fourth quarter of 2004.

\section{Other Data Requirements for Program-Monitoring Purposes}

26. Data on exports and imports, including volume and prices and compiled by the Director of Customs and the BCV, will be transmitted on a quarterly basis within five weeks after the end of each quarter. A preliminary quarterly balance of payments, compiled by the $\mathrm{BCV}$, will be forwarded within five weeks after the end of each quarter.

27. The monthly disaggregated consumer price index for Cape Verde, compiled by the National Institute of Statistics (INE), will be transmitted monthly, within five weeks after the end of each month.

28. Documentation of all measures taken by the government to meet performance criteria or indicative benchmarks under the program will be transmitted to the Fund staff within one week after the day of implementation. 
Press Release No. 05/16

FOR IMMEDIATE RELEASE

February 1, 2005
International Monetary Fund

Washington, D.C. 20431 USA

\section{IMF Executive Board Completes Fifth Review Under Cape Verde's PRGF Arrangement and Approves US\$1.9 Million Disbursement}

The Executive Board of the International Monetary Fund (IMF) has completed the fifth review of Cape Verde's economic performance under an SDR 8.64 million (about US\$13.1 million) Poverty Reduction and Growth Facility (PRGF) arrangement (see Press Release No. 02/18). The completion of this review enables the release of a further SDR 1.23 million (about US\$1.9 million), which would bring the total amount drawn under the arrangement to SDR 7.38 (about US\$11.2 million).

In completing the fifth review, the Executive Board granted Cape Verde's request to extend the arrangement to end-July 2005. Cape Verde's three-year PRGF arrangement was approved on April 10, 2002.

Following the Executive Board's discussion of Cape Verde, on January 31, 2005, Agustín Carstens, Deputy Managing Director and Acting Chair, stated:

"Cape Verde continues to demonstrate strong economic performance, supported by the authorities' adherence to prudent macroeconomic policies and their commitment to structural reform. Although growth appears to have slowed modestly during 2004 owing to short-term difficulties in the agricultural sector and public investment program, it is expected to pick up again in 2005. Furthermore, fiscal performance in 2004 was better than expected, external balances improved, international reserves accumulation was higher than had been targeted, and inflation remained very low.

"The authorities' proposed policy stance for 2005 is appropriately focused on maintaining macroeconomic stability, ensuring the credibility of the exchange rate peg to the euro, and pushing ahead with needed reforms, including through the implementation of the Poverty Reduction Strategy Paper (PRSP). Going forward, the authorities will need to maintain expenditure restraint, including on wages, in the lead-up to the elections in January 2006, and continue to improve revenue performance by further strengthening tax administration and reining in tax exemptions. The monetary stance must also remain consistent with low inflation, the growth of real activity, and the targeted increase in reserves. 
"It will be important for the authorities to move ahead with the determined implementation of key structural reforms, including the completion of the privatization agenda by early 2006 , and steps to enhance the business environment. They should also make every effort to regularize the government's financial relations with the electricity and water utility, Electra, to reduce fiscal risks. Furthermore, the Economic Regulatory Agency should rapidly implement the automatic mechanism for setting electricity and water tariffs, and ensure that the adjustment mechanism for retail fuel prices is applied systematically. Adequate social safety nets to cushion the impact of these measures on the poor will need to be considered.

"The recently completed PRSP provides an appropriate framework for addressing Cape Verde's development challenges. Looking forward, the authorities should continue to seek external grants and concessional financing for the envisioned reforms, improve domestic resource mobilization, and strengthen prioritization among the PRSP's objectives," Mr. Carstens said.

The PRGF is the IMF's concessional facility for low-income countries. PRGF loans carry an annual interest rate of 0.5 percent, and are payable over 10 years with a $5 \frac{1 / 2-y e a r}{\text { grace period on }}$ principal payments. 


\section{Statement by Damian Ondo Mañe, Executive Director for Cape Verde January 31, 2005}

On behalf of my Cape Verdean authorities I would like to thank staff for their continuous support under the current PRGF arrangement and for the constructive policy advice provided. Such advice has been instrumental in implementing the macroeconomic and structural policies that will enable Cape Verde to reach higher and more sustainable growth rates consistent with poverty reduction. I also welcome the report's well balanced assessment of Cape Verde's performance. While my authorities appreciate the candid acknowledgement of their economic and social achievements under the program, they also share the assessment of risks and challenges highlighted by staff for the period ahead. In requesting the completion of the Fifth Review under the PRGF arrangement, my authorities would like to add a request for a short extension of the arrangement to end-July 2005, to allow them to provide sufficient time for completion of the final review.

Cape Verde continues to perform well under the PRGF arrangement; all quantitative and structural performance criteria for end-June 2004, and all indicative targets for endDecember 2004 have been observed. The delay in adopting regulations for the determination of electricity and water tariffs (a structural performance benchmark that has not yet been met) stems from the difficulties to find consultants to conduct this work. Consultants have now been engaged and work is underway with the assistance of the World Bank. The issue of the government's financial liabilities to the electricity and water company, Electra, is a complex one deriving from the non-adjustment of energy tariffs to international oil prices in recent years, and hence creating huge liabilities for the government. My authorities recognize the need to regularize their financial obligations to Electra and are making every effort to settle past liabilities to the privatized company. In this regard, the government of Cape Verde has cleared its arrears to Electra on its consumption of water and electricity, and has initiated an arbitration process with the water and electricity company to identify the government's liabilities. They also recognize that the adoption of an automatic and transparent mechanism to determine electricity and water tariffs by the independent Economic Regulatory Agency will represent an important step to avoid the recurrence of such complications.

Cape Verde's macroeconomic indicators are sound and tend to exceed program targets. In the fiscal area, revenues under the VAT -introduced a year ago-, have largely exceeded expectations. As regards monetary policy, the net international reserves of the Bank of Cape Verde also exceeded the program target by a wide margin, giving assurances to the market that the authorities are determined to maintain and strengthen the peg with the euro. This peg has served the country well notably by reducing the pressure of high oil prices on the economy. The current account deficit continues to improve under strong tourism receipts and high remittances from the expatriate population.

However, growth was revised downward as a consequence of the adverse impact of poor rainfall and locust infestation on the agricultural sector, particularly in the island of Santo Antão. A lower than expected public investment program due to administrative delays in managing the programming cycle, also negatively affected growth. However, public and 
private investments are expected to pick up in 2005, because of higher investments in the tourism sector and the construction of airports.

Major challenges in Cape Verde stem from the country's insularity (it is an archipelago of 10 inhabited islands), and from the difficulty of developing agriculture due to the nature of the soil. Hence, more than 80 percent of the food has to be imported, though 70 percent of the population still lives in rural areas. My authorities share staff's concern regarding the challenges highlighted in the report, including high costs of energy distribution, shipping and air links across the archipelago and a low agriculture and energy potential. The government development strategy rightly builds on the geographic specificities of the country, by focusing on growth of the tourism sector and the promotion of Cape Verde as a shipping and airline hub. Ongoing public investment projects such as the new international airport in the capital Praia, and in the island of Boa Vista, are in support of a development strategy that aims at improving international air access to the different islands, and at lowering interislands costs of travel and transport, while contributing to the promotion of tourism. Other major private investments in the short-term include hotels in the islands of Sal and Boa Vista. The government is also making efforts to attract foreign direct investment and stimulate export activity through a newly established free trade zone and the completion of an industrial park in Mindelo.

\section{Fiscal Policy}

The fiscal deficit in 2004 will be much lower than projected due to the stronger than expected performance of revenue collection. The introduction of the VAT last year, and the modernization and streamlining of the tax system (elimination of many consumption taxes, reduction of imports taxes), has contributed to boost fiscal revenue. However, recurrent spending has been revised upward to support increased hiring and training of teachers doctors, and policemen. Extraordinary expenditures have also increased in response to the locust infestation, the drought and higher fuel prices. However, lower than programmed public investments have offset these increases.

Nevertheless, the authorities have maintained a prudent fiscal stance and are committed to contain recurrent spending, including the wage bill. As such, they will implement their poverty reduction strategy at a pace that is consistent with macroeconomic stability while providing scope for increases in priority spending especially in infrastructure, health, and the education sectors. Efforts to strengthen tax administration are also underway following the recommendations of a recent mission from the Fund's Fiscal Affairs Department.

\section{Monetary Policy and Current Account}

The authorities' monetary framework is designed to support price stability and the accumulation of international reserves to back the exchange rate peg. Such a framework has enabled Cape Verde to maintain a low level of inflation. My authorities recognize that key to the success of this framework is a policy of continued fiscal prudence to minimize government's recourse to domestic bank credit. Growth of credit to the economy was slower in 2004 than 2003, in part due to the slowdown in economic activity and high lending rates of 
commercial banks which also contributed to the subdued inflation (other factors that maintained prices low are the strong agricultural performance during the 2003-04 season and the reductions in customs tariffs).

The current account deficit will likely narrow in 2005, notwithstanding high international oil prices. The value of oil imports in dollar terms will partly be offset by the appreciation of the Cape Verdean escudo against the dollar (the escudo is pegged to the euro). High revenues in the tourism sector and the continuous flow of remittances from the diaspora will also support the reduction of the current account deficit.

\section{Structural Reforms}

Structural reforms have focused on the restructuring and privatization of major public enterprises. The government is making progress in implementing its structural reform agenda, and is committed to completing the privatization of the maritime transport company (Arca Verde), a dockyard (CABNAVE), the pharmaceutical manufacturer and distributor (EMPROFAC), a fish freezing and storage company (Interbase), and two ports, by the end of 2005. The airline company is also being prepared for privatization following the recent appointment of a new management team. The restructuring of the airline company represents an essential piece of the government's development strategy, based on improving international air access to the different islands and lowering inter-islands costs of travel and transport.

The difficulties with Electra have shown that an important part of the privatization process consists in the development of regulatory capacities in the various sectors that are being restructured. As such, the authorities are currently putting in place regulatory capacities in the maritime and pharmaceutical sectors.

The government of Cape Verde has adopted in February 2004, a mechanism to adjust retail fuel prices in response to changes in import prices of oil products. However, prior to the November 2004 adjustment, only one adjustment had taken place. Such delays result from the difficulties encountered by the regulatory agency in its negotiations with the two oil importing companies. However, the authorities have reiterated their commitment to systematically implement the mechanism beginning in January 2005.

\section{PRSP}

My authorities welcome the comments provided by staff on their PRSP, and they would like to reassure the Board that they will continue to make every effort to seek external grants and concessional financing to support the PRSP investment program to accelerate the fight against poverty, unemployment, and inequality. We urge the international community to increase their support to Cape Verde, in light of the sound performance of its economy. My authorities are also making efforts to improve domestic resource mobilization and strengthen prioritization within the PRSP, including through the medium term expenditure framework that the government has begun to develop. The key macroeconomic assumptions included in the framework are consistent with those of the PRGF arrangement. 


\section{Conclusion}

The government of Cape Verde has reiterated its desire to continue its excellent working relationship with the Fund through a new arrangement, once the current PRGF comes to an end in July 2005. A successor program would reassure the donor community of the Fund's involvement in the economic developments in Cape Verde. In this regard, my authorities are committed to implementing policies that support macroeconomic stability and the credibility of the exchange rate peg. They recognize the risks and challenges ahead, and, in particular, they are determined to make every effort to avoid fiscal slippages during the upcoming elections.

Cape Verde is a stable democracy and a strong economic performer that deserves continuous support from the international community, including through an increase in concessional lending and the provision of grants. We particularly call on the U.S. authorities to support Cape Verde's request for funding from the Millennium Challenge Account that will enable it to strengthen competitiveness and support rural development. 